\title{
The fat and the bad: Mature adipocytes, key actors in tumor progression and resistance
}

\author{
Minh Ngoc Duong ${ }^{1}$, Aline Geneste ${ }^{2}$, Frederique Fallone ${ }^{3}$, Xia Li ${ }^{3}$, Charles Dumontet ${ }^{2,4}$ \\ and Catherine Muller ${ }^{3}$ \\ ${ }^{1}$ Department of Oncology/CHUV-UNIL, Biopole 3, Epalinges, Switzerland \\ ${ }^{2}$ Centre de Recherche en Cancérologie de Lyon (CRCL), INSERM UMR 1052/CNRS 5286, Lyon, France \\ ${ }^{3}$ Institut de Pharmacologie et de Biologie Structurale (IPBS), Université de Toulouse, CNRS, UPS, Toulouse, France \\ ${ }^{4}$ Hospices Civils de Lyon, Lyon, France
}

Correspondence to: Minh Ngoc Duong, email: mn.duong@hotmail.com

Keywords: adipocytes, adipose tissue, cancer progression, invasion, resistance

Received: December 06, 2016

Accepted: May 08, 2017

Published: May 20, 2017

Copyright: Duong et al. This is an open-access article distributed under the terms of the Creative Commons Attribution License 3.0 (CC BY 3.0), which permits unrestricted use, distribution, and reproduction in any medium, provided the original author and source are credited.

\section{ABSTRACT}

Growing evidence has raised the important roles of adipocytes as an active player in the tumor microenvironment. In many tumors adipocytes are in close contact with cancer cells. They secrete various factors that can mediate local and systemic effects. The adipocyte-cancer cell crosstalk leads to phenotypical and functional changes of both cell types, which can further enhance tumor progression. Moreover, obesity, which is associated with an increase in adipose mass and an alteration of adipose tissue, has been established as a risk factor for cancer incidence and cancer-related mortality. In this review, we summarize the mechanisms of the adipocyte-cancer cell crosstalk in both obese and lean conditions as well as its impact on cancer cell growth, local invasion, metastatic spread and resistance to treatments. Better characterization of cancer-associated adipocytes and the key molecular events in the adipocyte-cancer cell crosstalk will provide insights into tumor biology and suggest efficient therapeutic opportunities.

\section{INTRODUCTION}

Adipose tissue (AT) is one of the main components of the human body. Imaging methods, including computed tomography, magnetic resonance imaging and ultrasound, have allowed the quantification of adipose tissue. The latter was estimated to represent $18-25 \%$ of the body mass in a reference man, $25-31 \%$ in a reference woman, and higher percentage in overweight people [1]. Based on its biological functions, AT can be classified into two main types: white adipose tissue (WAT) localized subcutaneously, surrounding visceral organs or in the breast in females (mammary adipose tissue or MAT) [2] and brown adipose tissue (BAT) in paracervical and supraclavicular regions [3-5]. While WAT is specialized in storing energy and is an important endocrine organ involved mainly in the control of weight regulation, the BAT is the main tissue regulating thermogenesis in response to food intake and cold. A new type of adipocytes has been recently described, referred to as the brite, also called beige, adipocytes. Beige adipocytes share some common features with brown adipocytes, such as the expression of mitochondrial uncoupling protein 1 (UCP1) despite the fact that they reside in WAT, predominantly in subcutaneous WAT [6]. Finally, several «non typical » AT have been described such as the one included in the bone marrow. Bone marrow adipocytes (BM-Ad) possess unique profiles and have been proposed to exhibit features of beige or brown-like adipocytes [7-9].

WAT, which is the main focus of this review, is highly complex in terms of cellular composition, including mature adipocytes, pre-adipocytes, fibroblasts, pericytes, endothelial cells, and immune cells. Although adipocytes were estimated to account for only $14-24 \%$ of the adipose tissue cell populations $[10,11]$, due to their large size, adipocytes are still considered as the major component of AT. For a long time, adipocytes from WAT were viewed as a simple passive energy storage depot. 
However, since the discovery of leptin in 1994, the role of adipocytes has evolved into an active source of various paracrine and endocrine factors. These adipocyte-secreted factors constitute a group of molecules named adipokines, including common growth factors, hormones, cytokines, chemokines, and also specific factors such as leptin, adiponectin. To date, more than 400 factors have been reported to be released by adipocytes, and this number is still increasing [12]. These adipocyte-derived factors, acting locally or systemically, could play important roles in the growth, local invasion, metastatic spread and resistance to treatments of different types of cancer. Studying the role of adipocytes in cancer occurrence or progression is of major clinical interest due to the established link between obesity and cancer. Obesity is a pathological condition accompanied by an excessive fat deposition and is often estimated through the measure of body mass index (BMI) (weight in $\mathrm{kg} /$ height in $\mathrm{m}^{2}$ ). It is due to an imbalance between dietary energy intake and energy output [13]. The excessive energy intake in obese people is stored mainly in adipose tissue that increases in mass. The expansion of adipose tissue is essentially due to an increase in adipocyte volume (hypertrophy) and to a lesser extent to an increase in adipocyte cell number (hyperplasia) [14, 15]. Importantly, obesity is not only related to an increase in adipose quantity, but also an alteration of adipose quality. Obese adipose tissue has been characterized as being in a chronic inflammation state, with remodeling of local adipose tissue and dysregulation of secreted adipokines [16]. In addition to cardiovascular disease and type 2 diabetes mellitus, overweight and obesity are now established risk factors for cancer and cancer-related mortality. Excess body weight increases incidence of several types of cancer including, among the most frequent, oesophageal adenocarcinoma, colorectal, endometrial and post-menopausal breast cancer. Obesity also portends worse cancer-specific outcomes after diagnosis in several tumor types including those of the breast (independently of menopausal status), oesophagus, colon, prostate and others $[17,18]$. This relationship has major consequences in public health since the prevalence of overweight and obesity has been increasing worldwide over the past decades and reaches alarming proportions. According to the World Health Organization (WHO), worldwide obesity has more than doubled since 1980 and in 2014, more than 1.9 billion adults were overweight and of these over 600 million were obese. It has been estimated that by 2025 , global obesity prevalence will continue to increase, reaching $18 \%$ in men and more than $21 \%$ in women [19].

The precise mechanisms underlying the obesitycancer link are not yet well understood. However, it is tempting to speculate that, within a context of obesity, adipocytes, due to their dysfunctional state, could be more prone to contribute to a favorable environment for the development of tumor cells. This review will summarize the impact of mature adipocytes on the biological characteristics of cancer cells. We will focus on adipocytes from WAT, referred as adipocytes in this review, since they are the most documented. However, the emerging role of BM-Ad on cancer will be also highlighted across the review. The crosstalk between adipocytes and cancer cells will be detailed in both lean and obese conditions, and its potential therapeutic implication for cancer treatment will be discussed. Due to space limitations, the role of other cellular components of AT in cancer progression will not be discussed. However, very interesting results have been obtained with adipose progenitors whose implication in tumor progression has been highlighted for example in a recent review on breast cancer [20]. Besides, the impact of obesity-related metabolic disorders on cancer, such as hyperinsulinemia and insulin resistance, has been reviewed elsewhere $[17,21]$. Moreover, the modification of the immune environment (including the recruitment of pro-inflammatory macrophages) arising in AT during obesity is also probably very important in terms of cancer progression. Readers interested in these aspects could refer to recent reviews $[22,23]$.

\section{Adipocytes and cancer cells: close neighbours}

Regarding the role of AT in cancer progression, local tissue-specific effects must be viewed with particular attention. Due to the distribution of AT in different organs, adipocytes are in close contact with cancer cells in many solid tumors during tumor growth, local invasion or bone metastasis as well as in hematological malignancies. The most prominent example of this proximity is in breast. Structurally, a normal breast is composed of an epithelial compartment (mammary gland) embedded in a stroma referred to as the mammary fat pad. Unlike murine mammary fat pad which is mainly composed of adipocytes, the human mammary fat pad is also enriched in connective tissue [24]. Therefore, while murine mammary epithelium is directly adjacent to adipocytes, human mammary epithelium is separated from adipocytes by a fibrous layer. However, in certain situations such as mammary involution or tumor invasion, the mammary extracellular matrix is remodeled, resulting in a direct contact between epithelial cells and adipocytes [25]. Similarly, the vicinity between adipocytes and cancer cells has also been observed in invasive melanoma, prostate, colon and ovarian cancers [26-28]. Furthermore, it is worth noting that the bone marrow is a niche for hematological malignancies and a metastatic site of many cancers, such as breast and prostate. Adipocytes constitute a major component of the bone marrow stroma $[8,9]$ and importantly, the adipose mass is increased with obesity and aging which could have an impact on cancer development in obese and/or elderly patients $[29,30]$.

As a consequence of the close localization between adipocytes and invasive cancer cells, adipocytes in the vicinity of cancer cells display profound phenotypic and 
functional alterations. Histological images of solid tumors consistently showed a decrease in both cell number and cell size of adipocytes located at the invasive front compared to adipocytes distant from the tumor [28, 31]. Moreover, at the tumor center, there is an increase in the ratio of fibroblast-like cells [32], suggesting a "dedifferentiation" of adipocytes induced by cancer cells. We have shown that these phenotypical changes can be reproduced in vitro using a co-culture system where the two populations are separated by an insert. Co-culture of adipocytes with cancer cells for 3 to 5 days lead to adipocyte delipidation and decreased expression of adipocyte markers such as Ap2 (FABP4), adiponectin, and hormone-sensitive lipase [31]. Additionally, co-cultured adipocytes displayed modifications of their secretome, notably an upregulation of osteopontin, matrix metalloproteinase 11 and inflammatory cytokines such as TNFa, IL-6 and IL-1 $\beta[31,33]$. Such an activated phenotype has been confirmed in vivo at the invasive front of human breast tumors [31, 34] (Figure 1). Together, these in vitro and in vivo data indicate that adipocytes are modified by cancer cells to acquire characteristics different from those of naive adipocytes. We named them cancerassociated adipocytes (CAAs) [35]. Moreover, upon prolonged exposure to tumor cells, mature adipocytes completely lose their lipid content and exhibit fibroblastlike morphology highlighting that they contribute to the cancer-associated fibroblast population [36], which are known to further enhance tumor progression and metastasis [37]. In fact, in all tumors growing in an adipose tissuedominated microenvironment (gastric, breast, colon, renal, prostate and ovarian cancers and melanoma), it is now admitted that when the tumor invades the surrounding AT, adipocytes disappear, fibroblast-like cells accumulate, and a desmoplastic stroma ensues (for review see [38]). Similar lipid loss has been observed in vitro when BM-Ad (obtained from ex vivo differentiation of bone marrow mesenchymal stem cells) are cocultured with prostate cancer cells [39], suggesting that CAAs might also occurs at bone metastatic sites. The origin of these phenotypic and functional alterations in adipocytes is only partially characterized. In breast cancer, we have demonstrated that occurrence of the CAA phenotype depends on the reactivation of the Wnt/bcatenin pathway in response to Wnt3a secreted by tumor cells [36]. Thus, this crosstalk should be taken in account when considering the paracrine role of AT, since consistent results show that adipocytes are not inert actors in regards to their surrounding within the tumor. Since most of the experimental studies performed emphasize the paracrine role of adipocytes, we will focus on this aspect of the adipocyte/ cancer cell crosstalk. Nevertheless, AT also constitutes an active endocrine organ that can have far-reaching effects on the physiology of other tissues. To understand the endocrine effect of adipose tissue on cancer the reader is referred to reviews on that topic [40-42].

\section{Role of mature adipocytes in cancer progression: effect on tumor growth, local invasion and metastasis}

\section{Adipocytes support tumor growth}

Several studies have demonstrated the role of adipocytes and AT in the support and the promotion of tumor growth. Elliott et al. showed that murine mammary carcinoma cells grew better when injected in the mesenteric and ovarian fat pad or in the mammary gland than in subcutis or the peritoneal cavity. Moreover, co-transplantation of these cancer cells with mammary or ovarian fat fragments into the subcutis increased the
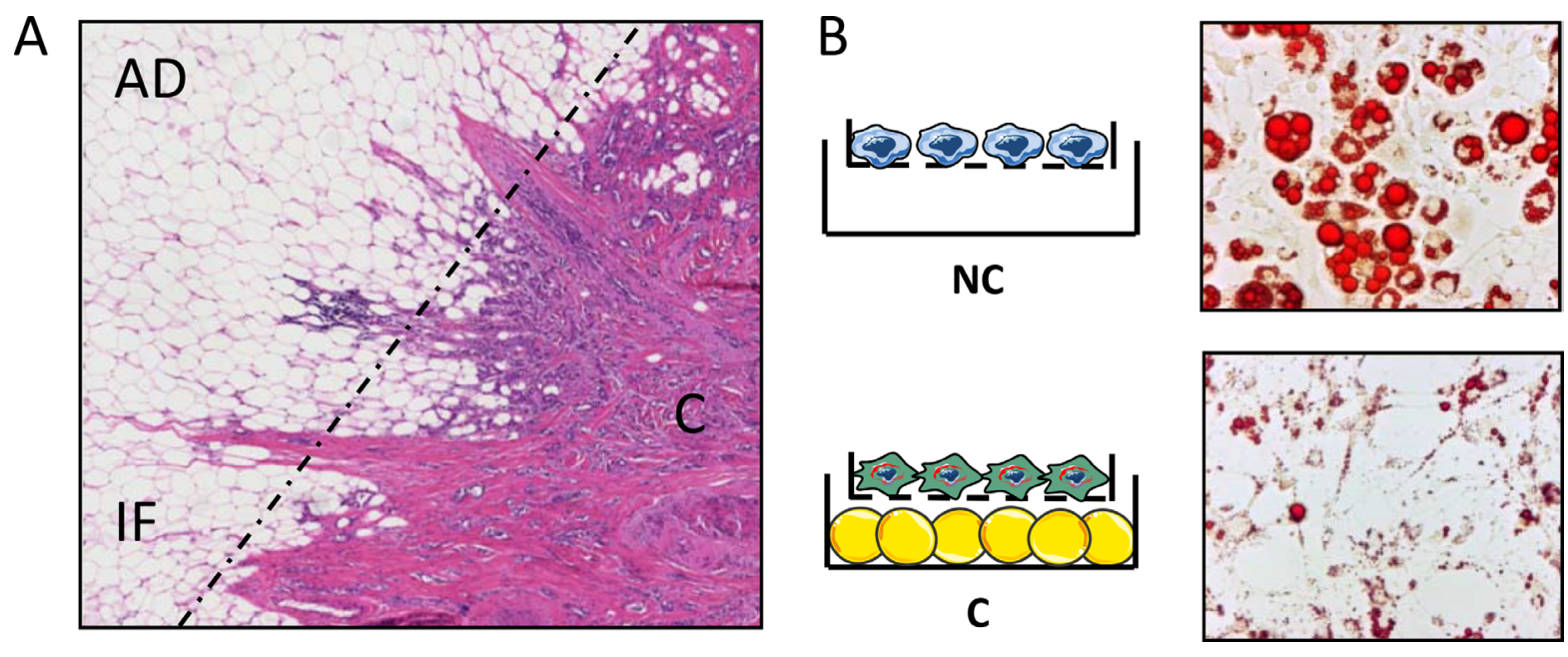

Figure 1: In breast cancers, adipocytes localized at the tumor invasive front undergo decrease in size and lipid content, a process that can be recapitulated in vitro, in co-culture assays. (A) Histological examination of an invasive breast tumor after H\&E staining (original magnification $\times 100$ ). AD, adipose tissue; IF, invasive front (indicated by a dashed line); (C) tumor center. Note that at the invasive front, the size of adipocytes is reduced. (B) Mature adipocytes cocultivated in the presence (C) or absence (NC) of breast cancer cells were stained with oil Red $\mathrm{O}$. The cocultivated adipocytes exhibit a decrease in the number and size of lipid droplets. 
tumor growth [43]. Manabe and colleagues showed that mature rat adipocytes, but not rat pre-adipocytes, increased tumor growth of estrogen receptor-positive $(\mathrm{ER}+)$ breast carcinoma cell lines [44]. More recently, Nieman et al. showed that co-culture of human adipocytes with ovarian cancer cells promoted cancer cell growth both in vitro and in vivo [28]. A similar effect of promoting tumor growth by adipocytes has been observed in prostate cancer, colon cancer and melanoma in vitro [45-48]. Emerging studies suggest that the growth promoting-effect of adipocytes is also observed at bone metastatic sites with an increase in bone tumor burden after intratibial injection of prostate cancer and melanoma cells in high fat diet-induced obese mice $[39,49]$. Despite the evidence that adipocytes could promote tumor growth, the relationship between tumor growth and adipocytes might be more complex than that initially thought. For example, we have shown that some breast tumor cell lines co-cultivated with adipocytes exhibit increased proliferation, but this was not a general effect in contrast to the effect on invasion [31]. Similar results were obtained with prostate and melanoma cell lines ([50], Muller et al., unpublished results). Interestingly, a recent work performed in vivo in a large number of breast tumors (around 1000) showed that estrogen receptornegative breast tumors at the close proximity of adipose tissue exhibited significantly lower mitotic index when compared with that of the tumor cells on the gland side [51]. In association to our in vitro results, these compelling results emphasize that the effect of adipocytes on tumor cell proliferation might be more complex than initially thought and depend on the tumor model used. This aspect will clearly need additional studies. Nevertheless, since a growth-promoting effect has been largely reported in several models, the mechanisms involved in this phenomenon will be described in the following paragraph.

\section{Adipocytes secrete adipokines promoting tumor growth}

Many tumor cells express receptors for the adipokines secreted by adipocytes, which can affect tumor growth. These adipocyte-derived factors include mainly leptin, adiponectin, estrogen, insulin-like growth factor 1 (IGF-1) and hepatocyte growth factor (HGF).

\section{Leptin and adiponectin}

The role of leptin in tumorigenesis was suggested by the high expression of the leptin receptor (ObR) in several cancer cells, such as breast, stomach, colon, ovarian cancers and leukemia [52-56]. In addition, the fact that leptin secretion is clearly up-regulated in obesity contributes to generate significant interest around this adipokine [57]. In vitro studies using recombinant leptin showed its ability to increase cancer cell proliferation via the activation of ERK1/2 and c-Jun NH2-terminal kinase (JNK) pathways [58]. Amemori et al. showed in a three dimensional collagen gel culture system, that adipocytes from wild-type mice increased the proliferation of colon cancer cells and that this effect was abolished in adipocytes from $o b / o b$ mice deficient for leptin [47]. These results indicate that leptin enhances tumor cell growth in vitro. However, the in vivo role of leptin in tumorigenesis remains controversial. While $o b / o b$ mice displayed decreased growth of colorectal and mammary tumors [59, 60], increased tumor growth was observed in prostate tumors [61]. Additionally, Aparicio et al. showed that leptin induced growth of colon cancer cells in vitro but not in nude mice and in $\mathrm{Apc}^{\mathrm{Min} /+}$ mice that were susceptible to spontaneous intestinal adenoma formation [62]. These apparent contradictory observations of tumor growth in vivo could be partly explained by the concurrent local and systemic effects of leptin on adjacent tumor cells and immune cells, respectively. Indeed, leptin was also shown to be important in development and cytotoxicity of immune cells $[63,64]$.

On the other hand, a number of human cancers were observed to express high levels of the adiponectin receptors (AdipoR1 and AdipoR2) [65-68], an adipokine whose secretion is down-regulated in obesity [69]. In vitro exposure of cancer cells to adiponectin inhibited proliferation and induced apoptosis in different cancer cell lines, such as breast, liver, colon, stomach and endometrium $[65,70-74]$. In vivo, adiponectin reduced tumorigenesis of many cancer cells $[72,73,75,76]$, and adiponectin deficiency promoted tumor growth $[77,78]$. The growth inhibition of adiponectin in cancer cells was shown to be mediated through activation of AMPK, inhibition of PI3K/ Akt and ERK1/2 pathways, down-regulation of leptininduced STAT3 phosphorylation, inhibition of NF- $\kappa$ B and Wnt/ $\beta$-catenin pathways, and decrease of ROS production [79]. Thus, adiponectin mediates effects on tumor growth opposite to those of leptin.

Since both adipokines are secreted by adipocytes and present in the blood, the leptin:adiponectin ratio may be a major factor influencing tumor growth. It is worth noting that in obese patients, plasma concentration of leptin is increased, while that of adiponectin is decreased [57, 69]. Clinical studies have indicated a positive correlation between a high leptin:adiponectin ratio and an increased risk of postmenopausal breast [80,81], colorectal [82] and endometrial cancers [83]. Interestingly, cancer-associated adipocytes displayed decreased expression of adiponectin [31], suggesting a hijacking of adipocytes by cancer cells to promote tumor growth.

\section{Insulin-like growth factor 1}

High levels of circulating IGF-1 have been correlated with increased risk in many cancers, including premenopausal breast, prostate, lung and colorectal cancers [84]. Tumor cells were shown to express IGF-1R, 
and binding of IGF-1R to its ligand promotes cell growth and survival through activation of PI3K/Akt and MAPK pathways $[84,85]$. Adipocytes were shown to secrete IGF-1, and obesity is associated with increased levels of IGF-1 [86]. Interestingly, inhibition of IGF-IR kinase activity prevented the growth-promoting effect of adipocytes on breast cancer cells [87].

\section{Hepatocyte growth factor}

Hepatocyte growth factor (HGF) was shown to be secreted by human adipocytes and the production of HGF by adipocytes contributed to its elevated serum level in obesity [88]. In parallel, the HGF receptor (c-Met) was found to be expressed in breast and ovarian cancers [89, 90]. Interestingly, it was observed that in breast cancer samples, c-Met expression was increased at the adipocyte-tumor interface [91]. This expression pattern suggests a paracrine interaction between adipocytes and tumor cells. Rahimi et al. showed that HGF promoted proliferation of murine breast carcinoma SP1 cells [92]. Moreover, neutralization of $\mathrm{HGF}$ in the conditioned medium from murine 3T3-L1 adipocytes suppressed the adipocyte-induced proliferation of SP1 cells [92]. In vivo, overexpressing HGF in different tissues in mice resulted in tumorigenesis of those tissues [93]. Interestingly, a recent study by Sundaram in obese mice showed that weight loss reversed obesity-induced HGF/c-Met pathway and basallike breast cancer progression [94].

\section{Estrogen}

Estrogen receptors are expressed by cancer cells in breast and ovarian cancers [95]. Estrogen plays a crucial role in the promotion of growth in hormone-dependent cancers [96]. Although AT is a major source of estrogen, adipose stromal cells but not mature adipocytes were shown to express aromatase, the key enzyme in estrogen production $[97,98]$. Interestingly, aromatase expression in stromal cells is induced by tumor cells via the secretion of PGE2 [99, 100]. Since CAAs were shown to acquire fibroblast-like characteristics [36], one might hypothesize that these adipocyte-derived fibroblasts could also produce estrogen and contribute to tumor growth. Importantly, in case of obesity, adipocytes can indirectly induce the expression of aromatase in breast cancer cells and AT via the recruitment of macrophages. Recent studies by Arendt et al. demonstrated that obese adipocytes secrete CCL2 and IL-1 $\beta$ which lead to the accumulation of macrophages surrounding dead adipocytes, forming crown-like structures [101]. Exposure of M1 macrophages to saturated fatty acids released as a result of obesity-associated lipolysis leads to the secretion of proinflammatory mediators, including PGE2, TNF- $\alpha$, IL-1 $\beta$, and IL- 6 . These molecules upregulate the expression of CYP19, the gene encoding estrogen synthase aromatase in adipose tissue and breast cancer epithelium, causing estrogen production and contributing to obesity-associated breast cancer [102].

\section{Other adipokines}

IL-6 has been shown to promote tumor growth in different types of cancer [103]. Although IL-6 could be secreted by a various sources in the tumor microenvironment, including tumor cells, tumor-infiltrating macrophages, T cells, we and others have shown that IL-6 is highly secreted in CAA [28, 31]. Recently, Chen et al. demonstrated that marrow adipocytes in the vicinity of the tumor cells expressed high levels of IL-6, and blockade of IL- 6 by neutralizing antibody blocked tumor growth of melanoma cells [49]. Intriguingly, the antitumor effect of anti-IL-6 antibody was only observed in high fat dietinduced obese mice but not in mice with normal diet [49]. This data underlines the importance of a pro-inflammatory microenvironment in obese conditions that could enhance tumor growth.

Resistin is another adipokine that has been linked to promoting tumor growth. Kim et al. showed that resistin induced prostate cancer cell proliferation through PI3K/ Akt pathway [104]. In another study, Deshmukh et al. showed that resistin promotes growth and aggressiveness of breast cancer cells through STAT3 activation [105]. Adenylyl cyclase-associated protein 1 (CAP1) was identified as a functional receptor for human resistin to modulate inflammatory action in monocytes [106]. However, the expression of CAP1 or of other resistin receptors and their intracellular signaling pathways in different cancer cells remains to be determined. Circulating levels of resistin are increased in obesity [107], and epidemiological studies suggested a link between resistin levels and cancer risk [108].

Overall, above is a non-exhausted list of adipokines that could impact on tumor growth. It is worth noting that although the secretion of these adipokines is inherent property of adipocytes, it is strongly modulated along the acquisition of fibroblastic-like characteristics of CAA. While adipocyte terminal markers such as adiponectin, leptin and resistin are decreased in CAA, inflammatory cytokines such as IL-6 are increased. Further studies are required to better understand their individual contributions and their cooperation in tumor progression in the context of the tumor microenvironment, as well as the modulation of their corresponding receptors during tumor progression in different types of cancer.

\section{Adipocytes promote angiogenesis}

Angiogenesis, the process of new blood vessel formation, plays a critical role in tumor expansion [109]. Blood vessels supply oxygen, nutrients, and growth factors from the plasma to tumor cells. In parallel, increase of adipose mass, in particular in obesity, is also 
associated with angiogenesis. This process is tightly regulated by tumor cells and stromal cells in the tumor microenvironment. It has been shown that adipocytes actively participate in angiogenic modulation through the secretion of adipokines [110, 111]. Classical angiogenic factors, such as vascular endothelial growth factor A (VEGFA), are produced by adipocytes in response to insulin [112]. Moreover, leptin could directly promote proliferation and angiogenic differentiation of endothelial cells which express leptin receptor [113]. Importantly, leptin was shown to upregulate VEGF in breast cancer via HIF-1 and NFאB; thus it could confer an additional advantage to tumors under hypoxic conditions [114]. Other adipokines, such as resistin, angiopoetin, and HGF also promote angiogenesis in vitro and in vivo [111, 115-118]. By contrast, the role of adiponectin in angiogenesis is debatable. While some studies showed that adiponectin may be pro-angiogenesis $[77,115,116,119,120]$, other studies reported an inhibition of angiogenesis both in vitro and in vivo [121, 122]. Besides, certain adipocyte-derived lipids such as monobutyrin were also shown to induce angiogenesis [123]. Recently, Lim et al. showed that inoculation in WAT and BAT of different tumor types, including breast, melanoma and fibrosarcoma, resulted in marked increased of tumor growth rate relative to subcutaneous implementation [124]. Tumors implemented in WAT or BAT displayed augmented angiogenesis, blood perfursion and decreased hypoxia compared to subcutaneous tumors [124]. Interestingly, BAT is more efficient to induce tumor growth than WAT. The authors correlated this difference to the degree of pre-existing vascularization in those tissues. However, the impact of the adipocyte-cancer cell crosstalk on angiogenesis was not clear in this study and requires further investigations [124].

\section{Adipocytes provide energy to fuel tumor growth}

The "Warburg effect", in which oxidative phosphorylation is shifted to glycolysis to rapidly provide energy for tumor growth, even under normal oxygenic conditions, has been described in cancer cells several decades ago [125]. In parallel, cancer cells are capable of using alternative sources of energy, such as amino acids and lactate from the microenvironment $[126,127]$. In 2009, Lisanti et al. proposed the "reverse Warburg effect": cancer cells induce glycolysis in cancer-associated fibroblasts which in turn produce lactate and pyruvate for cancer cell metabolism and proliferation [128, 129]. This concept could be applied to other cells of the tumor stroma, notably adipocytes. These cells have been shown to release lactate through the monocarboxylate transporters, in particular under hypoxic conditions $[130,131]$. However, several published studies demonstrated that the source of energy provided by adipocytes to cancer cells is lipids. As stated before, co-culture of adipocytes with breast cancer cells led to adipocyte delipidation [31]. In line with these data, we showed that CAAs located at the invasive front of breast cancer displayed smaller sizes and less lipid than adipocytes far from the tumors [31], an observation that has been largely confirmed by several groups in a wide range of solid tumors $[25,38,132]$. These phenotypic changes were initially associated with adipocyte "dedifferentiation" [31] but additional studies from our lab and others demonstrated that cancer cells also induce lipolysis in adipocytes [28, 133-135]. The free fatty acids (FFAs) liberated by adipocytes are then taken up by tumor cells and stored as lipid droplets to avoid lipotoxicity, both in vitro and in vivo [28, 48, 135]. Among FFAs, palmitic acid was shown to be the major FFA transferred from adipocytes to melanoma cells [48].

What is the fate of FFAs in cancer cells? In ovarian cancers, co-culture with adipocytes was associated with an up-regulation of the rate of fatty acid $\beta$-oxydation (FAO), a metabolic pathway that yields a large quantity of ATP [28]. At physiological levels, FAO is carried out in energy-demanding tissues (such as the heart and skeletal muscle) and recent works also brought to light a role for this metabolic pathway in cancer that seems to be highly responsive to environmental changes [136]. However, the involvement of this increased FAO in ATP production and growth-promoting effect of adipocytes has not been directly demonstrated in the ovarian cancer model [28]. In breast cancer, our most recent results demonstrated that increased FAO is dissociated from ATP production, this uncoupled FAO promoting an increase in invasion, but not proliferation, of cancer cells both in vitro and in vivo [135]. Therefore, although the lipid transfer between tumorsurrounding adipocytes and cancer cells appears to be a general phenomenon, the fate of these transferred FFAs might be dependent on the model studied. Similar lipid transfer between tumor cells and BM-Ad has been shown in vitro [39]. In opposition to the increase in FAO observed at primary sites, a recent study proposed that the crosstalk between prostate tumor cells and bone marrow adipocytes led to decreased mitochondrial oxidative phosphorylation in tumor cells associated to increased expression of glycolytic enzymes and increased lactate production via oxygen-independent mechanism of HIF-1 $\alpha$ activation [133]. These differences suggest that the metabolic phenotype of tumor cells could also be dependent on the type of adipocytes surrounding the tumors.

What are the molecular actors that allow this transfer of FFAs between adipocytes and cancer cells? Fatty acid-binding protein 4 (FABP4) was identified as a key mediator in this process. In fact, FABP4 expression is increased in tumor cells cocultivated with adipocytes in vitro and in human tumors that invade AT [28]. Similar up-regulation of FABP4 was observed in tumor cells cocultivated with BM-Ad and in murine models of bone metastasis of prostate cancer [39]. Inhibition of FABP4 by small molecules reduced lipid accumulation in cancer cells in co-culture experiments with adipocytes, and 
Fabp4-/- mice presented significantly reduced ovarian tumor growth [28]. However, the factors that induce the first step of the crosstalk which is the initiation of lipolysis in adipocytes remain poorly described. Besides, it has been reported that exosomes derived from pancreatic cancer cells induce lipolysis in subcutaneous adipose tissue, exosomal adrenomedullin being a candidate mediator of this effect [137]. It remains to be determined whether this pathway might be operational in other tumor types. Besides, it is worth noting that induced lipolysis of adipose tissue contributes to cancer-associated cachexia [138], a syndrome characterized by the loss of adipose and muscle mass and frequently observed in untreated cancer patients [139]. Inflammatory cytokines made by host and/or tumor cells, such as TNF- $\alpha$, IL-1, IL- 6 and IFN- $\gamma$, have been reported to induce cancer cachexia in animal models [139]. In our hands, blocking TNF $\alpha$ or IL-6 was unable to prevent the delipidation of adipocytes induced by tumor cells in our co-culture system, suggesting that they are not involved and/or sufficient to explain this paracrine and "acute" delipidation [36]. Recently, Kir and al. identified parathyroid hormone-related protein (PTHrP), a tumorderived small polypeptide, as an inducer of thermogenic gene expression and wasting in adipocytes [140, 141]. Neutralization of PTHrP by a specific antibody in tumorbearing mice attenuated weight loss and mice lacking PTHrP receptor in adipose tissues are resistant to tumordriven cachexia $[140,141]$. Thus, PTHrP might represent an interesting candidate. Taken together, these data indicate that there is a metabolic crosstalk between adipocytes and cancer cells. Further studies are required to identify the key molecular actors in this process, the fate of transferred FFAs and its potential as a target in cancer therapy.

\section{Adipocytes promote tumor invasion and metastasis}

Metastasis is a major cause of cancer-related death. Several clinical studies have shown a positive correlation between AT infiltration of different types of cancer and poor prognosis [86]. As we will see, during the invasion and metastatic processes, adipocytes can play important roles either by increasing cancer cell migration and invasion, remodeling of the extracellular matrix, or promoting tumor homing.

\section{Adipocytes increase cancer cell migration and invasion}

Experiments showing the impact of adipocytes on cancer cell aggressiveness were mostly performed in vitro using co-culture system. We and others have shown that co-cultures of adipocytes with breast cancer cells increased cancer cell migration and invasion $[31,32,36]$. Moreover, co-cultured breast cancer cells displayed a downregulation of the epithelial marker E-cadherin and a reorganization of $\beta$-catenin without a simultaneous increase in mesenchymal markers [31]. These data suggest an incomplete induction of epithelial mesenchymal transition (EMT) by adipocytes. The invasion-promoting effect of adipocytes seems to not be dependent on cell-cell contact but mediated by soluble factors secreted by these cells. Interestingly, only the conditioned medium from CAAs, but not from "naive" adipocytes which had never been co-cultured with tumor cells, increased the invasive capacity of breast cancer cells [31]. Increased migratory and invasive abilities of tumor cells cocultivated with adipocytes have been observed with other models such as prostate cancer $[46,50]$. Similar findings were obtained with prostate cancer cells cocultivated with BM-Ad [29]. This data strongly illustrates the cancer-adipocyte crosstalk and its importance in the modulation of tumor progression.

Several factors have been identified to be secreted by adipocytes and be involved in the invasion-promoting effect. In breast cancer, IL-6 was shown to be secreted by adipocytes, notably at high levels by CAAs [31]. Moreover, IL-6 promotes tumor migration and invasion, and its inhibition by blocking antibodies significantly reduces these effects [31]. Such an inflammatory state in the tumor-surrounding adipose tissue has also been described for prostate cancer. High levels of IL- 6 were found in the peri-prostatic adipose tissue of tumor-bearing patients and the levels of IL-6 correlated with the aggressiveness of the tumors, highlighting the importance of this cytokine in the adipocyte/cancer cells crosstalk [27]. Another adipocyte-secreted factor, leptin, was shown to promote breast cancer cell migration and invasion via IL-18 expression and secretion [142]. Additionally, fatty acid transfer from marrow adipocytes could stimulate invasion of prostate cancer cells, which is decreased upon inhibition of FABP4 [143, 39]. Furthermore, we have recently uncovered that exosomes secreted by adipocytes promoted melanoma migration and invasion in vitro and in vivo, this effect being enhanced in case of obesity [144]. Exosomes are nanovesicles secreted by most cell types, which allow the transfer of lipids, proteins and nucleic acids between cells. A proteomic study further demonstrated that these vesicles carry proteins implicated in FAO, a feature highly specific to adipocyte exosomes. Transfer of these proteins from adipocytes to tumor cells is likely to promote the observed increase in tumor migration. In fact, in the presence of adipocyte-derived exosomes, FAO was increased in melanoma cells and pharmacological inhibition of this metabolic pathway completely abrogated the exosome-mediated increase in migration [144].

\section{Adipocytes remodel the extracellular matrix}

Adipocytes secrete various constituents of the extracellular matrix, such as different types of collagen [145]. During tumorigenesis, cancer cells have been shown to upregulate the secretion of collagen VI by adipocytes 
[146]. Collagen VI was shown to promote tumor growth and survival via signaling through the NG2/chondroitin sulfate proteoglycan receptor expressed on tumor cells [147]. In the case of induced expression of the mouse mammary tumor virus/polyoma virus middle $\mathrm{T}$ oncogene, mice lacking collagen VI exhibited reduced rates of hyperplasia and primary tumor growth. Particularly, adipocytes from collagen-deficient mice were less potent in stimulating tumor growth [147]. Furthermore, endotrophin, a cleaved fragment of the collagen VI $\alpha 3$ chain, promoted the EMT process and metastatic spread of mammary epithelial cancer cells [148].

Adipocytes also secrete a number of matrix metalloproteinases (MMP) which allow the remodeling of the extracellular matrix [149]. Many MMPs have been shown to be involved in the promotion of tumor invasion [150]. Importantly, cancer cells were shown to induce the expression of MMP-11 in adipocytes as tumor invaded the surrounding adipose tissue [34]. Although the substrates of MMP-11 remain unknown [151], some studies suggested that MMP-11 can cleave collagen VI [152]. In vivo, MMP-11 was shown to promote cancer progression by remodeling the extracellular matrix and downregulation of MMP-11 by siRNA attenuated cancer metastasis [153-155]. Additionally, high levels of MMP-11 expression were correlated with increased invasion and bad prognosis in breast carcinoma [156], pancreatic cancer [157] and colon cancer [158]. In parallel, MMP-11 can directly act on adipocytes and negatively regulate adipogenesis by inhibiting adipocyte differentiation and by enhancing dedifferentiation, leading to accumulation of fibroblast-like cells in the tumor microenvironment [152]. Furthermore, adipokines such as leptin or HGF can induce the secretion of various MMPs by cancer cells, thus indirectly promoting tumor invasion [159-161].

\section{Adipocytes promote tumor homing and seeding at distant organs}

Adipose tissues are preferential metastatic sites of several cancers. Nieman et al. showed that omentum adipocytes favored tumor homing via secretion of cytokines and chemokines [28]. The most abundantly adipocyte-secreted cytokines included IL-6, IL-8, MCP-1, and tissue inhibitor of metalloproteinase-1 (TIMP-1). Antibody-mediated inhibition of these factors reduced ovarian cancer cell homing toward adipocytes in vitro [28]. Neutralization of IL-6R and particularly IL-8R (CXCR1) reduced in vivo homing of ovarian cancer cells to the mouse omentum [28]. Notably, the expression of IL-8R was strongly upregulated in ovarian cancer cells in co-culture with adipocytes. In another study, Pramanik et al. showed that acute lymphoblastic leukemia (ALL) cells migrated into adipose tissues in vivo and exhibited chemotaxis towards adipocytes in vitro [162]. CXCL12/SDF-1 was identified as an adipocyte-derived chemoattractant responsible for leukemia cell migration. Inhibition of the SDF-1 receptor, CXCR4, in ALL cells abrogated their migration toward adipocytes. In prostate cancer ( $\mathrm{PCa})$, we uncovered that periprostatic adipose tissue (PPAT) was able to support the directed migration of tumor cells, therefore favoring the dissemination of the cancer outside of the prostate gland [163]. The secretion, by mature adipocytes of the periprostatic fat, of the chemokine MCP-3/CCL7 supports this process and within the context of obesity this secretion is increased. The receptor for this chemokine, CCR3, has been identified in PCa cells. Blocking the CCL7/CCR3 axis inhibited PCa local invasion in vitro and in vivo with a striking effect in obese animals. More importantly, expression of this receptor was associated with aggressiveness in PCa patients and was correlated with extra-prostatic dissemination and surgical treatment failure [163]. Finally, it has been suggested using human bone tissue fragments that breast cancer cells exhibit in vitro directed migration towards BM-Ad that correlated with leptin and IL1ß levels of expression [164], a process that needs to be confirmed in vivo.

Altogether, these data illustrate that mature adipocytes can act at each key step of the metastatic process, the main findings being summarized in Figure 2. These effects are mediated through the release of soluble factors (including pro-inflammatory cytokines and chemokines), ECM components as well as through the active release of exosomes. The relative contribution of these different mechanisms remains unknown. Increase in invasive capacities is a very important aspect of the adipocyte/cancer crosstalk. These results should be further considered in light of the clinical studies that show an increase in local and distant dissemination of both prostate and breast cancers in obese patients [165].

\section{Adipocytes increase cancer cell survival and resistance to therapies}

Several studies have shown that stromal cells such as fibroblasts could promote survival and drug resistance in cancer [166]. However, little is known about the impact of adipocytes in the efficiency of anti-cancer therapies. The first evidence of the protective role of adipocytes on cancer cells came from the observation by Iyengar et al., who showed that 3T3-L1 adipocytes supported survival of transformed ductal epithelial cells in vitro under limiting serum conditions [146]. Other epidemiological and experimental studies, including ours, have demonstrated the involvement of adipocytes in the evasion of cell death and promotion of cancer resistance to therapies.

\section{Epidemiological evidence linking obesity and tumor resistance to therapies}

As stated before, obesity has been clearly associated with higher mortality in obese cancer patients compared to lean cancer patients [167]. This could be partly due to the 
presence of more advanced diseases in obese patients at the time of diagnosis [17]. Moreover, the under-dosing of therapy regimens by clinicians due to the fear of toxicity could also contribute to the decrease in treatment efficacy [168]. Accordingly, recent recommendations highlighted that full weight-based chemotherapy doses need be used in the treatment of obese patients with cancer, especially when the goal of treatment is cure [168]. In addition, it has also been proposed that obesity can alter the pharmacokinetics of drugs used in chemotherapy [142, 143]. However, independently of these parameters, clinical data have shown that obesity could have an independent effect in cancer resistance to therapies [165].

Concerning the impact of AT on sensitivity to radiotherapy, the results remain controversial since some studies have shown an adverse effect of obesity on clinical outcome of prostate cancer patients [171-173], while other reports have indicated no difference in efficacy between obese and lean patients in prostate and esophageal cancers [174-176]. By contrast, the link between obesity and resistance seems to be more firmly established for chemotherapy and endocrine therapy. In a study by Ewertz and colleagues on 53,816 women with early-stage breast cancer treated with different regimens of chemotherapy or endocrine therapy (tamoxifen or aromatase inhibitors), the authors observed an increased risk of developing distant metastases in obese patients compared to lean patients [177]. In addition, both chemotherapy and endocrine therapy were found to be less effective in obese patients after 10 or more years of follow-up [177]. This finding of a negative impact of obesity in breast cancer was supported by another retrospective study by Jiralerspong on 6,342 patients with breast cancer [178]. In regards to targeted therapy, the impact of obesity on outcome has been investigated in only a few studies. In colorectal cancer, three retrospective trials have been conducted with conflicting conclusions. While Simkens et al. found that an increase in BMI was associated with a better overall survival in patients treated with chemotherapy, but not in patients treated with chemotherapy and bevacizumab, an anti-VEGF antibody [179]. Conversely, Guiu et al. showed that high BMI values and large visceral fat content were associated with poorer response, shorter time-to-progression and shorter overall survival in patients treated with bevacizumab and chemotherapy, but there was no significant association in patients treated with chemotherapy alone [180]. The negative impact of adiposity was supported by a study by Patel et al., in which the authors concluded that overweight BMI represented an independent, poor prognostic indicator for survival in patients undergoing chemotherapy with and without targeted therapy [181]. Besides, in breast cancer, Crozier et al. reported that adjuvant trastuzumab, an antiHER2 antibody, improved the clinical outcome in a cohort of 3,017 patients regardless of their BMI [182].

Overall, further epidemiological studies are required to better understand the impact of high body adiposity on cancer survival, whether this was the case before or after diagnosis. Interestingly, several studies suggested that weight gain after diagnosis appeared to be associated with greater disease mortality [165]. However, whether weight loss after diagnosis may Local dissemination \& adipose
tissue infiltration

\section{Crosstalk between cancer cells $\&$ adipocytes}

Distant dissemination

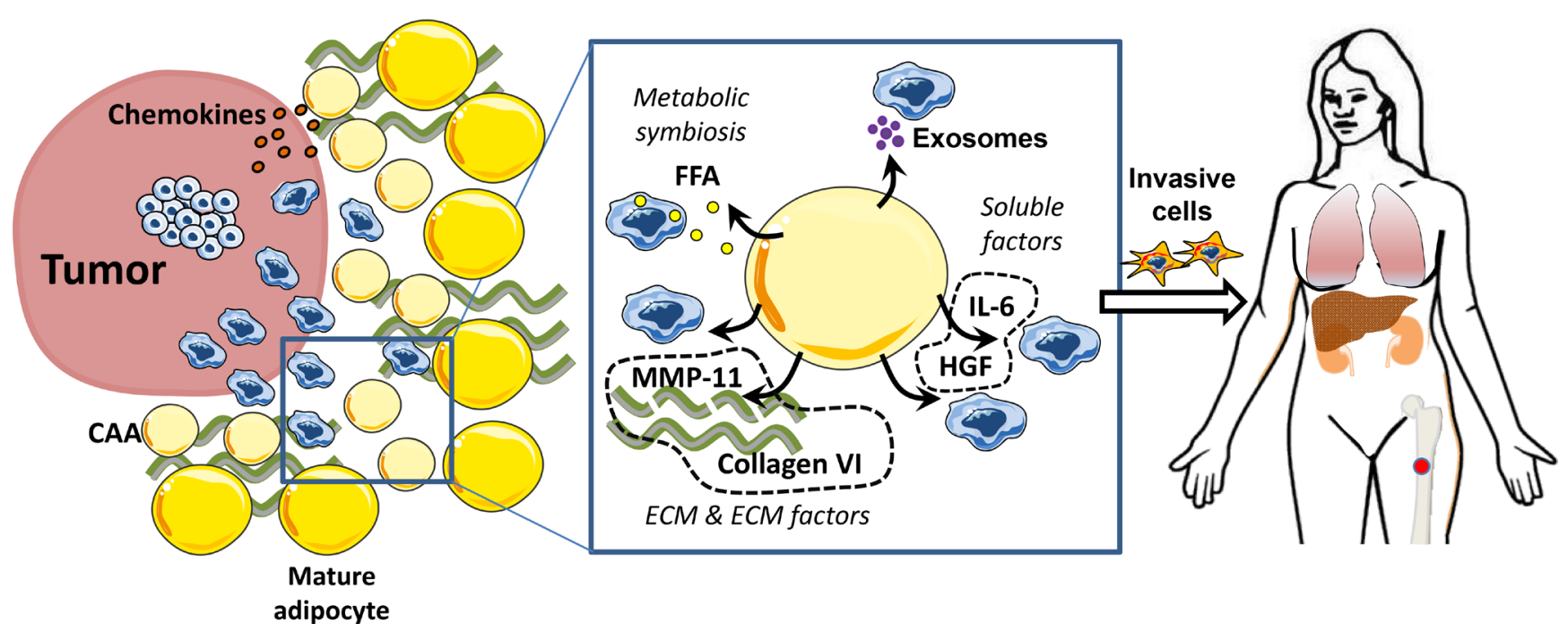

Figure 2: Adipocytes promote tumor invasion and metastasis. Secretion of cytokines and chemokines by mature adipocytes favor the homing of tumor cells to surrounding adipose tissue. Once the adipose tissue is invaded, a crosstalk is established between cancer cells and mature adipocytes that undergo phenotypical changes towards a Cancer Associated Adipocytes (CAAs) phenotype. Their ability to secrete soluble factors, exosomes and extra-cellular matrix components stimulate invasive properties of tumor cells. These invasive cells can enter the blood stream and colonize distant organs including bone which is also an adipocyte-rich organ. 
improve prognosis remains unclear and requires further investigations [165].

\section{Adipocytes protect cancer cells via ECM}

One of the aspects of the environmental protection of cancer cells is the increase of cell adhesion to the extracellular matrix $[183,184]$. These interactions lead to the reorganization of cell cytoskeleton and activation of multiple transduction pathways, resulting in increased cell survival and resistance to chemotherapeutic agents. As previously mentioned, adipocytes are an abundant source of extracellular matrix components. Particularly, adipocytes which are in close contact with cancer cells secrete high levels of collagen VI [147]. In vitro exposure of tumor cells to collagen VI conferred resistance of ovarian cancer cells to cisplatin [185], possibly via the upregulation of metallothioneins which are known to play critical role in cisplatin resistance [186, 187]. Park et al. further showed that endotrophin, a cleavage product of collagen VI alpha 3 chain, enhanced EMT and caused resistance to cisplatin [188]. Interestingly, the same group showed that adipocytederived endotrophin could also induce adipose tissue fibrosis and inflammation [189], indicating mutual effects between tumor cells and CAAs.

\section{Adipocytes protect cancer cells via secretion of adipokines, metabolites or exosomes}

As previously discussed, adipocytes are source of various paracrine factors and many of them have been shown to be responsible for cancer resistance to therapies.

The main mechanisms involved in adipocytesinduced resistance have been the modulation of cell death pathways. Behan et al. showed that adipocytes protected acute lymphoblastic leukemia cells from cytotoxic agents, including vincristine, dexamethasone, daunorubicin, and nilotinib in vitro [190]. This protection was independent of cell-cell contact and was associated with increased expression of pro-survival signals Bcl-2 and Pim-2 in cancer cells [190]. In another study, Chi et al. showed that adipocyte-secreted leptin contributed to resistance of melanoma cells to various therapeutic agents, including cisplatin, docetaxel, and the histone deacetylase inhibitor SAHA [191]. This was associated with increased activation of survival pathways PI3K/Akt and MEK/ ERK. Enhancement of prosurvival pathways by leptin has also been shown to counteract the cytotoxic effect of 5-fluorouracil, a common therapeutic agent for colon cancer [192]. In the same line of findings, we previously reported that mature adipocytes could protect breast cancer cells from ionizing radiation-inducing post-mitotic cell death. This effect was due to the secretion of IL-6 by tumor cells, secretion that was upregulated in the presence of adipocytes [193]. In another study, we showed that adipocytes could protect HER2-positive breast cancer cells from trastuzumab-mediated cellular cytotoxicity in vitro and from antitumor effect of trastuzumab in vivo [194]. Interestingly, this protective effect was enhanced under hypoxic conditions [194], underlying the importance of adipocytes in the tumor microenvironment and/or obesity. Adipocyte-secreted factors rapidly activated Akt survival pathway in cancer cells and upregulated the expression of several genes involved in cell survival [194]. More importantly, the protection of tumor cells by adipocytes seems not to be limited to monoclonal antibodies such as trastuzumab or the drug-antibody conjugate T-DM1, but also to kinase inhibitors (data not shown). Furthermore, in a recent study, it has been demonstrated that adipocytes could protect cancer cells by downregulating APAF1, a key protein involved in the formation of apoptosomes [195]. APAF1 was shown to be a direct target of miR21, which is abundantly present in exosomes isolated from CAAs and CAFs [195]. The authors showed that miR21 was transferred by exosomes from CAAs or CAFs to cancer cells, where it suppressed ovarian cancer apoptosis and conferred chemoresistance to paclitaxel by binding to its direct target, APAF1 [195].

Resistance to drugs induced by adipocytes is not limited to modulation of apoptosis. Pramanik et al. also demonstrated that both subcutaneous and visceral fat pads from obese and control mice protected acute lymphoblastic leukemia (ALL) cells from chemotherapy [162]. This protection was mediated via ALL-induced oxidative stress response in adipocytes and secretion of soluble factors by adipocytes [196]. However, the adipocytederived factors mediating resistance to chemotherapeutic agents were not clearly identified in these studies. Resistance to vincristine was also observed in vivo [190] and additional studies demonstrated that obesity altered vincristine pharmacokinetics in blood and tissues of mice, highlighting again that resistance to drugs induced by obesity is probably multifactorial [169]. Besides, a recent study by Liu et al. demonstrated that bone marrow adipocytes protected myeloma cells against chemotherapy through autophagy activation [197]. Leptin and adipsin were identified to be secreted by adipocytes and to be responsible for this mechanism of resistance [197].

In parallel, adipocytes could directly counteract the effects of chemotherapeutic agents by acting as source of metabolites, by modulating drug transport or intra-cellular metabolism. L-asparaginase is a first-line therapy for acute lymphoblastic leukemia (ALL) that breaks down asparagine and glutamine, two amino acids important in the metabolism of ALL. Ehsanipour et al. showed that adipocytes caused leukemic cell resistance to L-asparaginase via the release of glutamine [198]. Interestingly, these protective effects were observed with bone marrow-derived adipocytes in obesity, notably after the induction of chemotherapy. Another study showed that adipocyte-conditioned medium decreased tumor 
Table 1: Adipocytes increase cancer resistance to therapies

\begin{tabular}{|c|c|c|c|c|c|}
\hline Mechanism & $\begin{array}{l}\text { Tumor } \\
\text { model }\end{array}$ & Adipocyte model & Therapeutic agents & Observation & Reference \\
\hline $\begin{array}{l}\text { Enhanced } \\
\text { EMT process }\end{array}$ & $\begin{array}{l}\text { Mammary } \\
\text { tumors }\end{array}$ & Murine adipose tissue & Cisplatin & $\begin{array}{l}\text { COL6-/- mice or } \\
\text { thiazolidinediones or } \\
\text { endotrophin neutralizing } \\
\text { antibody sensitize tumors } \\
\text { to cisplatin treatment } \\
\text { in vivo }\end{array}$ & {$[188]$} \\
\hline \multirow{8}{*}{$\begin{array}{l}\text { Upregulation } \\
\text { of survival } \\
\text { gene } \\
\text { expression } \\
\text { and pro- } \\
\text { survival } \\
\text { pathways }\end{array}$} & \multirow{2}{*}{$\begin{array}{l}\text { Human } \\
\text { and murine } \\
\text { leukemia cell } \\
\text { lines }\end{array}$} & $\begin{array}{l}\text { 3T3-L1 murine cell } \\
\text { line, OP-9 murine bone } \\
\text { marrow-derived cell } \\
\text { line }\end{array}$ & \multirow{2}{*}{$\begin{array}{l}\text { Vincristine, } \\
\text { dexamethasone, } \\
\text { daunorubicin and } \\
\text { nilotinib }\end{array}$} & $\begin{array}{l}\text { Obesity impairs the effect } \\
\text { of vincristine in mice. }\end{array}$ & \multirow[b]{2}{*}[190]{} \\
\hline & & $\begin{array}{l}\text { Diet-induced obese } \\
\text { mice }\end{array}$ & & $\begin{array}{l}\text { Co-culture with } \\
\text { adipocytes decreases } \\
\text { chemotherapy-induced } \\
\text { cytotoxicity on leukemia } \\
\text { cells in vitro }\end{array}$ & \\
\hline & \multirow{3}{*}{$\begin{array}{l}\text { Human breast } \\
\text { cancer cell } \\
\text { lines }\end{array}$} & $\begin{array}{l}\text { 3T3F442A murine cell } \\
\text { line }\end{array}$ & Ionizing radiation & $\begin{array}{l}\text { Adipocytes lower } \\
\text { ionizing radiation- } \\
\text { induced cell death in vitro }\end{array}$ & [193] \\
\hline & & hMAD human cell line & \multirow[t]{2}{*}{ Trastuzumab } & $\begin{array}{l}\text { Adipocyte-conditioned } \\
\text { medium reduces } \\
\text { trastuzumab-induced } \\
\text { antibody-dependent } \\
\text { cellular cytotoxicity on } \\
\text { tumor cells in vitro }\end{array}$ & \multirow[t]{2}{*}[194]{} \\
\hline & & Human adipose tissue & & $\begin{array}{l}\text { Adipose tissue reduces } \\
\text { trastuzumab-induced } \\
\text { cytotoxicity on tumor } \\
\text { in vivo } \\
\end{array}$ & \\
\hline & $\begin{array}{l}\text { Melanoma } \\
\text { cell line }\end{array}$ & Human adipocytes & $\begin{array}{l}\text { Cisplatin, docetaxel, } \\
\text { and the histone } \\
\text { deacetylase } \\
\text { inhibitor SAHA }\end{array}$ & $\begin{array}{l}\text { Adipocyte-conditioned } \\
\text { media reduces sensitivity } \\
\text { to treatment-induced } \\
\text { apoptosis of melanoma } \\
\text { cells in vitro }\end{array}$ & {$[191]$} \\
\hline & $\begin{array}{l}\text { Human } \\
\text { colorectal } \\
\text { tumor stem } \\
\text { cells } \\
\end{array}$ & & 5-fluorouracil & $\begin{array}{l}\text { Leptin counteracts } \\
\text { cytotoxic effects of } \\
\text { 5-fluorouracil in vitro }\end{array}$ & [192] \\
\hline & $\begin{array}{l}\text { Human } \\
\text { ovarian } \\
\text { cancer cell } \\
\text { lines }\end{array}$ & $\begin{array}{l}\text { Adipocytes isolated } \\
\text { from omental tissues of } \\
\text { patients }\end{array}$ & Paclitaxel & $\begin{array}{l}\text { Downregulation of } \\
\text { APAF1 by adipocyte- } \\
\text { derived exosomal } \\
\text { microRNA21 enhances } \\
\text { chemoresistance in vitro } \\
\text { and in vivo }\end{array}$ & {$[195]$} \\
\hline \multirow{2}{*}{$\begin{array}{l}\text { Increase of } \\
\text { oxidative } \\
\text { stress } \\
\text { response }\end{array}$} & \multirow{2}{*}{$\begin{array}{l}\text { Human } \\
\text { and murine } \\
\text { leukemia cell } \\
\text { lines }\end{array}$} & $\begin{array}{l}\text { Subcutaneous and } \\
\text { visceral fat pads from } \\
\text { obese and control mice }\end{array}$ & \multirow{2}{*}{ Daunorubicin } & \multirow{2}{*}{$\begin{array}{l}\text { Co-culture with } \\
\text { adipocytes decreases } \\
\text { chemotherapy-induced } \\
\text { cytotoxicity on leukemia } \\
\text { cells }\end{array}$} & \multirow{2}{*}[162,196]{} \\
\hline & & $\begin{array}{l}\text { Murine 3T3L1 and } \\
\text { human Chub-S7 } \\
\text { adipocyte cell lines }\end{array}$ & & & \\
\hline
\end{tabular}




\begin{tabular}{|c|c|c|c|c|c|}
\hline \multirow[b]{2}{*}{$\begin{array}{l}\text { Autophagy } \\
\text { activation }\end{array}$} & $\begin{array}{l}\text { Multiple } \\
\text { myeloma } \\
(\mathrm{MM}) \text { human } \\
\text { cell lines } \\
\end{array}$ & \multirow{2}{*}{$\begin{array}{l}\text { Bone marrow isolated } \\
\text { adipocytes from } \\
\text { human, subcutaneous } \\
\text { fat and human pre- } \\
\text { adipocyte cell line } \\
\text { PCS-210-010 }\end{array}$} & \multirow{2}{*}{$\begin{array}{l}\text { Melphalan, } \\
\text { bortezomib, } \\
\text { dexamethasone, and } \\
\text { doxorubicin }\end{array}$} & \multirow{2}{*}{$\begin{array}{l}\text { Adipocyte-conditioned } \\
\text { media inhibit } \\
\text { chemotherapy-induced } \\
\text { apoptosis of MM cells in } \\
\text { vitro and in vivo }\end{array}$} & \multirow[b]{2}{*}{ [197] } \\
\hline & $\begin{array}{l}\text { Bone } \\
\text { marrow- } \\
\text { isolated MM } \\
\text { cells from } \\
\text { patients } \\
\end{array}$ & & & & \\
\hline \multirow{2}{*}{$\begin{array}{l}\text { Adipocyte- } \\
\text { secreted } \\
\text { glutamine }\end{array}$} & $\begin{array}{l}\text { Murine } \\
\text { and human } \\
\text { leukemia cell } \\
\text { lines }\end{array}$ & $\begin{array}{l}\text { 3T3-L1 murine cell } \\
\text { line, OP-9 murine bone } \\
\text { marrow-derived cell } \\
\text { line }\end{array}$ & \multirow{2}{*}{ L-asparaginase } & $\begin{array}{l}\text { Obesity impairs } \\
\text { L-asparaginase efficacy } \\
\text { in mice }\end{array}$ & \multirow{2}{*}{ [198] } \\
\hline & $\begin{array}{l}\text { Human } \\
\text { primary } \\
\text { leukemia } \\
\text { cells }\end{array}$ & $\begin{array}{l}\text { Diet-induced obese } \\
\text { mice }\end{array}$ & & $\begin{array}{l}\text { Adipocytes inhibit the } \\
\text { treatment-induced tumor } \\
\text { cell apoptosis in vitro }\end{array}$ & \\
\hline \multirow{2}{*}{$\begin{array}{l}\text { Dysregulation } \\
\text { of genes } \\
\text { involved in } \\
\text { gemcitabine } \\
\text { transport and } \\
\text { metabolism }\end{array}$} & \multirow{2}{*}{$\begin{array}{l}\text { Human } \\
\text { and murine } \\
\text { mammary } \\
\text { cancer cell } \\
\text { lines }\end{array}$} & $\begin{array}{l}\text { 3T3-L1 murine cell } \\
\text { line }\end{array}$ & \multirow[t]{2}{*}{ Gemcitabine } & $\begin{array}{l}\text { Adipocyte-conditioned } \\
\text { medium decreases } \\
\text { tumor cell response to } \\
\text { gemcitabine in vitro }\end{array}$ & \multirow[t]{2}{*}{ [199] } \\
\hline & & $\begin{array}{l}\text { Diet-induced obese } \\
\text { mice }\end{array}$ & & $\begin{array}{l}\text { Obesity induces } \\
\text { resistance to gemcitabine } \\
\text { in vivo }\end{array}$ & \\
\hline
\end{tabular}

cell response to gemcitabine in vitro. This increase in resistance seems to be due to modification of the expressions of genes involved in gemcitabine transport and metabolism in tumors [199].

Altogether, these data indicate that adipocytes could enhance cancer resistance to different types of therapies, through a variety of mechanisms (Table 1). They also suggest that the local microenvironment as well as metabolic factors need to be taken into account not only in assessing cancer risk, but also in the design of clinical trials in oncology.

\section{CONCLUSIONS}

Over the two past decades, with the increasing rates of obesity and metabolic disorders, as well as their link to cancer, adipocytes have increasingly received attention of researchers and clinicians. Growing evidence has transformed adipocytes from a passive, neutral cell type into an active actor playing important roles in both metabolic homeostasis and shaping of the microenvironment. Given the large volume of adipose cells and their proximity with cancer cells, adipocytes need to be considered as a major component in the microenvironment in many solid cancers, including breast, colon, prostate, ovarian cancers, as well as in hematological malignancies. It is important to underline the crosstalk between adipocytes and cancer cells, which leads to a profound modification of the adipocyte phenotype as well as the adipocyte secretome. These
CAAs could strongly support cancer progression through different axes: 1) they constitute a source of metabolites and adipokines to fuel tumor growth; 2) they promote invasive properties of tumor cells both at the primary tumor site and distant metastases; 3 ) they protect cancer cells against various therapies. Since obesity has become a global epidemic and it is commonly associated with poor prognosis in many cancers, it is of fundamental and clinical interest to further study the relationship between adipose tissue and cancer cells. Better characterization of CAAs and the key molecular events in the adipocyte-cancer cell crosstalk will provide insights into tumor biology and suggest efficient therapeutic opportunities.

\section{CONFLICTS OF INTEREST}

$\mathrm{CD}$ is a recipient of research grants from Roche. Other authors declare no conflicts of interest.

\section{FUNDING}

This work was supported by the Institut National du Cancer (INCa-DGOS-4664) and INCA PL-BIO 2013-106.

\section{REFERENCES}

1. American Council on Exercise. ACE Personal Trainer Manual: The Ultimate Resource for Fitness Professionals. American Council on Exercise; 2003. 
2. Shen W, Wang Z, Punyanita M, Lei J, Sinav A, Kral JG, Imielinska C, Ross R, Heymsfield SB. Adipose tissue quantification by imaging methods: a proposed classification. Obes Res. 2003; 11:5-16.

3. Cypess AM, Lehman S, Williams G, Tal I, Rodman D, Goldfine AB, Kuo FC, Palmer EL, Tseng Y-H, Doria A, Kolodny GM, Kahn CR. Identification and importance of brown adipose tissue in adult humans. N Engl J Med. 2009; 360:1509-17.

4. van Marken Lichtenbelt WD, Vanhommerig JW, Smulders NM, Drossaerts JMAFL, Kemerink GJ, Bouvy ND, Schrauwen P, Teule GJJ. Cold-activated brown adipose tissue in healthy men. N Engl J Med. 2009; 360:1500-8.

5. Virtanen KA, Lidell ME, Orava J, Heglind M, Westergren R, Niemi T, Taittonen M, Laine J, Savisto NJ, Enerbäck S, Nuutila P. Functional brown adipose tissue in healthy adults. N Engl J Med. 2009; 360: 1518-25.

6. Harms M, Seale P. Brown and beige fat: development, function and therapeutic potential. Nat Med. 2013; 19:1252-63.

7. Naveiras O, Nardi V, Wenzel PL, Hauschka PV, Fahey F, Daley GQ. Bone-marrow adipocytes as negative regulators of the haematopoietic microenvironment. Nature. 2009; 460:259-63.

8. Scheller EL, Doucette CR, Learman BS, Cawthorn WP, Khandaker S, Schell B, Wu B, Ding SY, Bredella MA, Fazeli PK, Khoury B, Jepsen KJ, Pilch PF, et al. Regionspecific variation in the properties of skeletal adipocytes reveals regulated and constitutive marrow adipose tissues. Nat Commun. 2015; 6:7808.

9. Scheller EL, Cawthorn WP, Burr AA, Horowitz MC, MacDougald OA. Marrow Adipose Tissue: Trimming the Fat. Trends Endocrinol Metab TEM. 2016; 27:392-403.

10. Suga H, Matsumoto D, Inoue K, Shigeura T, Eto H, Aoi N, Kato H, Abe H, Yoshimura K. Numerical measurement of viable and nonviable adipocytes and other cellular components in aspirated fat tissue. Plast Reconstr Surg. 2008; 122:103-14.

11. Eto H, Suga H, Matsumoto D, Inoue K, Aoi N, Kato H, Araki J, Yoshimura K. Characterization of structure and cellular components of aspirated and excised adipose tissue. Plast Reconstr Surg. 2009; 124:1087-97.

12. Zhong J, Krawczyk SA, Chaerkady R, Huang H, Goel R, Bader JS, Wong GW, Corkey BE, Pandey A. Temporal profiling of the secretome during adipogenesis in humans. J Proteome Res. 2010; 9:5228-38.

13. Caballero B. The global epidemic of obesity: an overview. Epidemiol Rev. 2007; 29:1-5.

14. Rosen ED, MacDougald OA. Adipocyte differentiation from the inside out. Nat Rev Mol Cell Biol. 2006; 7:885-96.

15. Sun K, Kusminski CM, Scherer PE. Adipose tissue remodeling and obesity. J Clin Invest. 2011; 121:2094-101.

16. Leal V de O, Mafra D. Adipokines in obesity. Clin Chim Acta. 2013; 419:87-94.
17. Calle EE, Kaaks R. Overweight, obesity and cancer: epidemiological evidence and proposed mechanisms. Nat Rev Cancer. 2004; 4:579-91.

18. Renehan AG, Tyson M, Egger M, Heller RF, Zwahlen M. Body-mass index and incidence of cancer: a systematic review and meta-analysis of prospective observational studies. Lancet Lond Engl. 2008; 371:569-78.

19. NCD Risk Factor Collaboration (NCD-RisC). Trends in adult body-mass index in 200 countries from 1975 to 2014: a pooled analysis of 1698 population-based measurement studies with 19.2 million participants. Lancet Lond Engl. 2016; 387:1377-96.

20. Bertolini F, Petit JY, Kolonin MG. Stem cells from adipose tissue and breast cancer: hype, risks and hope. Br J Cancer. 2015; 112:419-23.

21. Gallagher EJ, LeRoith D. The Proliferating Role of Insulin and Insulin-Like Growth Factors in Cancer. Trends Endocrinol Metab TEM. 2010; 21:610-8.

22. Conroy MJ, Dunne MR, Donohoe CL, Reynolds JV. Obesity-associated cancer: an immunological perspective. Proc Nutr Soc. 2016; 75:125-38.

23. Wright C, Simone NL. Obesity and tumor growth: inflammation, immunity, and the role of a ketogenic diet. Curr Opin Clin Nutr Metab Care. 2016; 19:294-9.

24. Hovey RC, McFadden TB, Akers RM. Regulation of mammary gland growth and morphogenesis by the mammary fat pad: a species comparison. J Mammary Gland Biol Neoplasia. 1999; 4:53-68.

25. Wang YY, Lehuédé C, Laurent V, Dirat B, Dauvillier S, Bochet L, Le Gonidec S, Escourrou G, Valet P, Muller C. Adipose tissue and breast epithelial cells: a dangerous dynamic duo in breast cancer. Cancer Lett. 2012; 324:142-51.

26. Proebstle TM, Huber R, Sterry W. Detection of early micrometastases in subcutaneous fat of primary malignant melanoma patients by identification of tyrosinase-mRNA. Eur J Cancer. 1996; 32A:1664-7.

27. Finley DS, Calvert VS, Inokuchi J, Lau A, Narula N, Petricoin EF, Zaldivar F, Santos R, Tyson DR, Ornstein DK. Periprostatic adipose tissue as a modulator of prostate cancer aggressiveness. J Urol. 2009; 182:1621-7.

28. Nieman KM, Kenny HA, Penicka CV, Ladanyi A, BuellGutbrod R, Zillhardt MR, Romero IL, Carey MS, Mills GB, Hotamisligil GS, Yamada SD, Peter ME, Gwin K, et al. Adipocytes promote ovarian cancer metastasis and provide energy for rapid tumor growth. Nat Med. 2011; 17:1498-503.

29. Hardaway AL, Herroon MK, Rajagurubandara E, Podgorski I. Bone marrow fat: linking adipocyte-induced inflammation with skeletal metastases. Cancer Metastasis Rev. 2014; 33:527-43.

30. Jöhrer K, Ploner C, Thangavadivel S, Wuggenig P, Greil R. Adipocyte-derived players in hematologic tumors: useful novel targets? Expert Opin Biol Ther. 2015; 15:61-77. 
31. Dirat B, Bochet L, Dabek M, Daviaud D, Dauvillier S, Majed B, Wang YY, Meulle A, Salles B, Le Gonidec S, Garrido I, Escourrou G, Valet P, et al. Cancer-associated adipocytes exhibit an activated phenotype and contribute to breast cancer invasion. Cancer Res. 2011; 71:2455-65.

32. Tan J, Buache E, Chenard MP, Dali-Youcef N, Rio MC. Adipocyte is a non-trivial, dynamic partner of breast cancer cells. Int J Dev Biol. 2011; 55:851-9.

33. Ribeiro RJT, Monteiro CPD, Cunha VFPM, Azevedo ASM, Oliveira MJ, Monteiro R, Fraga AM, Príncipe P, Lobato C, Lobo F, Morais A, Silva V, Sanches-Magalhães J, et al. Tumor cell-educated periprostatic adipose tissue acquires an aggressive cancer-promoting secretory profile. Cell Physiol Biochem Int J Exp Cell Physiol Biochem Pharmacol. 2012; 29: 233-40.

34. Andarawewa KL, Motrescu ER, Chenard MP, Gansmuller A, Stoll I, Tomasetto C, Rio MC. Stromelysin-3 is a potent negative regulator of adipogenesis participating to cancer cell-adipocyte interaction/crosstalk at the tumor invasive front. Cancer Res. 2005; 65:10862-71.

35. Dirat B, Bochet L, Escourrou G, Valet P, Muller C. Unraveling the obesity and breast cancer links: a role for cancer-associated adipocytes? Endocr Dev. 2010; 19:45-52.

36. Bochet L, Lehuédé C, Dauvillier S, Wang YY, Dirat B, Laurent V, Dray C, Guiet R, Maridonneau-Parini I, Le Gonidec S, Couderc B, Escourrou G, Valet P, et al. Adipocyte-derived fibroblasts promote tumor progression and contribute to the desmoplastic reaction in breast cancer. Cancer Res. 2013; 73:5657-68.

37. Cirri P, Chiarugi P. Cancer associated fibroblasts: the dark side of the coin. Am J Cancer Res. 2011; 1:482-97.

38. Nieman KM, Romero IL, Van Houten B, Lengyel E. Adipose tissue and adipocytes support tumorigenesis and metastasis. Biochim Biophys Acta. 2013; 1831:1533-41.

39. Herroon MK, Rajagurubandara E, Hardaway AL, Powell K, Turchick A, Feldmann D, Podgorski I. Bone marrow adipocytes promote tumor growth in bone via FABP4dependent mechanisms. Oncotarget. 2013; 4:2108-23. doi: 10.18632/oncotarget.1482.

40. Galic S, Oakhill JS, Steinberg GR. Adipose tissue as an endocrine organ. Mol Cell Endocrinol. 2010; 316:129-39.

41. Smitka K, Mare-ová D. Adipose Tissue as an Endocrine Organ: An Update on Pro-inflammatory and Antiinflammatory Microenvironment. Prague Med Rep. 2015; 116: 87-111.

42. Scheller EL, Burr AA, MacDougald OA, Cawthorn WP. Inside out: Bone marrow adipose tissue as a source of circulating adiponectin. Adipocyte. 2016; 5:251-69.

43. Elliott BE, Tam SP, Dexter D, Chen ZQ. Capacity of adipose tissue to promote growth and metastasis of a murine mammary carcinoma: effect of estrogen and progesterone. Int J Cancer. 1992; 51:416-24.

44. Manabe Y, Toda S, Miyazaki K, Sugihara H. Mature adipocytes, but not preadipocytes, promote the growth of breast carcinoma cells in collagen gel matrix culture through cancer-stromal cell interactions. J Pathol. 2003; 201:221-8.

45. Tokuda Y, Satoh Y, Fujiyama C, Toda S, Sugihara H, Masaki Z. Prostate cancer cell growth is modulated by adipocyte-cancer cell interaction. BJU Int. 2003; 91:716-20.

46. Moreira Â, Pereira SS, Costa M, Morais T, Pinto A, Fernandes R, Monteiro MP. Adipocyte secreted factors enhance aggressiveness of prostate carcinoma cells. PloS One. 2015; 10: e0123217.

47. Amemori S, Ootani A, Aoki S, Fujise T, Shimoda R, Kakimoto T, Shiraishi R, Sakata Y, Tsunada S, Iwakiri R, Fujimoto K. Adipocytes and preadipocytes promote the proliferation of colon cancer cells in vitro. Am J Physiol Gastrointest Liver Physiol. 2007; 292: G923-929.

48. Kwan HY, Fu X, Liu B, Chao X, Chan CL, Cao H, Su T, Tse AKW, Fong WF, Yu ZL. Subcutaneous adipocytes promote melanoma cell growth by activating the Akt signaling pathway: role of palmitic acid. J Biol Chem. 2014; 289:30525-37.

49. Chen GL, Luo Y, Eriksson D, Meng X, Qian C, Bäuerle T, Chen XX, Schett G, Bozec A. High fat diet increases melanoma cell growth in the bone marrow by inducing osteopontin and interleukin 6. Oncotarget. 2016; 7:26653-69. doi: 10.18632/oncotarget.8474.

50. Ribeiro R, Monteiro C, Cunha V, Oliveira MJ, Freitas M, Fraga A, Príncipe P, Lobato C, Lobo F, Morais A, Silva V, Sanches-Magalhães J, Oliveira J, et al. Human periprostatic adipose tissue promotes prostate cancer aggressiveness in vitro. J Exp Clin Cancer Res. 2012; 31: 32.

51. Ryu HS, Lee HB, Han W, Noh DY, Moon HG. Reduced proliferation in breast cancer cells contacting the neighboring adipocytes in human breast cancer tissues. Breast Cancer Res. 2015; 17:90.

52. Ishikawa M, Kitayama J, Nagawa H. Enhanced expression of leptin and leptin receptor (OB-R) in human breast cancer. Clin Cancer Res. 2004; 10:4325-31.

53. Mix H, Widjaja A, Jandl O, Cornberg M, Kaul A, Göke M, Beil W, Kuske M, Brabant G, Manns MP, Wagner S. Expression of leptin and leptin receptor isoforms in the human stomach. Gut. 2000; 47: 481-6.

54. Hardwick JC, Van Den Brink GR, Offerhaus GJ, Van Deventer SJ, Peppelenbosch MP. Leptin is a growth factor for colonic epithelial cells. Gastroenterology. 2001; 121:79-90.

55. Uddin S, Bu R, Ahmed M, Abubaker J, Al-Dayel F, Bavi P, Al-Kuraya KS. Overexpression of leptin receptor predicts an unfavorable outcome in Middle Eastern ovarian cancer. Mol Cancer. 2009; 8: 74.

56. Uddin S, Mohammad RM. Role of leptin and leptin receptors in hematological malignancies. Leuk Lymphoma. 2016; 57:10-6.

57. Considine RV, Sinha MK, Heiman ML, Kriauciunas A, Stephens TW, Nyce MR, Ohannesian JP, Marco CC, McKee LJ, Bauer TL. Serum immunoreactive-leptin concentrations in normal-weight and obese humans. N Engl J Med. 1996; 334:292-5. 
58. Garofalo C, Surmacz E. Leptin and cancer. J Cell Physiol. 2006; 207:12-22.

59. Endo H, Hosono K, Uchiyama T, Sakai E, Sugiyama M, Takahashi H, Nakajima N, Wada K, Takeda K, Nakagama H, Nakajima A. Leptin acts as a growth factor for colorectal tumours at stages subsequent to tumour initiation in murine colon carcinogenesis. Gut. 2011; 60:1363-71.

60. Zheng Q, Dunlap SM, Zhu J, Downs-Kelly E, Rich J, Hursting SD, Berger NA, Reizes O. Leptin deficiency suppresses MMTV-Wnt-1 mammary tumor growth in obese mice and abrogates tumor initiating cell survival. Endocr Relat Cancer. 2011; 18:491-503.

61. Ribeiro AM, Andrade S, Pinho F, Monteiro JD, Costa M, Lopes C, Aguas AP, Monteiro MP. Prostate cancer cell proliferation and angiogenesis in different obese mice models. Int J Exp Pathol. 2010; 91:374-86.

62. Aparicio T, Kotelevets L, Tsocas A, Laigneau JP, Sobhani I, Chastre E, Lehy T. Leptin stimulates the proliferation of human colon cancer cells in vitro but does not promote the growth of colon cancer xenografts in nude mice or intestinal tumorigenesis in Apc(Min/+) mice. Gut. 2005; 54:1136-45.

63. Tian Z, Sun R, Wei H, Gao B. Impaired natural killer (NK) cell activity in leptin receptor deficient mice: leptin as a critical regulator in NK cell development and activation. Biochem Biophys Res Commun. 2002; 298:297-302.

64. Lo CKC, Lam QLK, Yang M, Ko KH, Sun L, Ma R, Wang S, Xu H, Tam S, Wu CY, Zheng BJ, Lu L. Leptin signaling protects NK cells from apoptosis during development in mouse bone marrow. Cell Mol Immunol. 2009; 6:353-60.

65. Körner A, Pazaitou-Panayiotou K, Kelesidis T, Kelesidis I, Williams CJ, Kaprara A, Bullen J, Neuwirth A, Tseleni S, Mitsiades N, Kiess W, Mantzoros CS. Total and highmolecular-weight adiponectin in breast cancer: in vitro and in vivo studies. J Clin Endocrinol Metab. 2007; 92:1041-8.

66. Takahata C, Miyoshi Y, Irahara N, Taguchi T, Tamaki Y, Noguchi S. Demonstration of adiponectin receptors 1 and 2 mRNA expression in human breast cancer cells. Cancer Lett. 2007; 250:229-36.

67. Yoneda K, Tomimoto A, Endo H, Iida H, Sugiyama M, Takahashi H, Mawatari H, Nozaki Y, Fujita K, Yoneda M, Inamori M, Nakajima N, Wada K, et al. Expression of adiponectin receptors, AdipoR1 and AdipoR2, in normal colon epithelium and colon cancer tissue. Oncol Rep. 2008; 20:479-83.

68. Dalamaga M, Migdalis I, Fargnoli JL, Papadavid E, Bloom E, Mitsiades N, Karmaniolas K, Pelecanos N, Tseleni-Balafouta S, Dionyssiou-Asteriou A, Mantzoros CS. Pancreatic cancer expresses adiponectin receptors and is associated with hypoleptinemia and hyperadiponectinemia: a case-control study. Cancer Causes Control. 2009; 20:625-33.

69. Arita Y, Kihara S, Ouchi N, Takahashi M, Maeda K, Miyagawa J, Hotta K, Shimomura I, Nakamura T, Miyaoka K, Kuriyama H, Nishida M, Yamashita S, et al. Paradoxical decrease of an adipose-specific protein, adiponectin, in obesity. Biochem Biophys Res Commun. 1999; 257:79-83.

70. Kang JH, Lee YY, Yu BY, Yang BS, Cho KH, Yoon DK, Roh YK. Adiponectin induces growth arrest and apoptosis of MDA-MB-231 breast cancer cell. Arch Pharm Res. 2005; 28:1263-9.

71. Dieudonne MN, Bussiere M, Dos Santos E, Leneveu MC, Giudicelli Y, Pecquery R. Adiponectin mediates antiproliferative and apoptotic responses in human MCF7 breast cancer cells. Biochem Biophys Res Commun. 2006; 345:271-9.

72. Saxena NK, Fu PP, Nagalingam A, Wang J, Handy J, Cohen C, Tighiouart M, Sharma D, Anania FA. Adiponectin modulates $\mathrm{C}$-jun $\mathrm{N}$-terminal kinase and mammalian target of rapamycin and inhibits hepatocellular carcinoma. Gastroenterology. 2010; 139:1762-73, 1773.e1-5.

73. Ishikawa M, Kitayama J, Yamauchi T, Kadowaki T, Maki T, Miyato H, Yamashita H, Nagawa H. Adiponectin inhibits the growth and peritoneal metastasis of gastric cancer through its specific membrane receptors AdipoR1 and AdipoR2. Cancer Sci. 2007; 98:1120-7.

74. Cong L, Gasser J, Zhao J, Yang B, Li F, Zhao AZ. Human adiponectin inhibits cell growth and induces apoptosis in human endometrial carcinoma cells, HEC-1-A and RL95 2. Endocr Relat Cancer. 2007; 14:713-20.

75. Wang Y, Lam JB, Lam KSL, Liu J, Lam MC, Hoo RLC, $\mathrm{Wu} \mathrm{D}$, Cooper GJS, $\mathrm{Xu} \mathrm{A}$. Adiponectin modulates the glycogen synthase kinase-3beta/beta-catenin signaling pathway and attenuates mammary tumorigenesis of MDAMB-231 cells in nude mice. Cancer Res. 2006; 66:11462-70.

76. Otani K, Kitayama J, Yasuda K, Nio Y, Iwabu M, Okudaira S, Aoki J, Yamauchi T, Kadowaki T, Nagawa H. Adiponectin suppresses tumorigenesis in $\operatorname{Apc}(\mathrm{Min})(/+)$ mice. Cancer Lett. 2010; 288:177-82.

77. Sun Y, Lodish HF. Adiponectin deficiency promotes tumor growth in mice by reducing macrophage infiltration. PloS One. 2010; 5:e11987.

78. Nishihara T, Baba M, Matsuda M, Inoue M, Nishizawa Y, Fukuhara A, Araki H, Kihara S, Funahashi T, Tamura S, Hayashi N, Iishi H, Shimomura I. Adiponectin deficiency enhances colorectal carcinogenesis and liver tumor formation induced by azoxymethane in mice. World $\mathrm{J}$ Gastroenterol. 2008; 14:6473-80.

79. Dalamaga M, Diakopoulos KN, Mantzoros CS. The role of adiponectin in cancer: a review of current evidence. Endocr Rev. 2012; 33:547-94.

80. Ollberding NJ, Kim Y, Shvetsov YB, Wilkens LR, Franke AA, Cooney RV, Maskarinec G, Hernandez BY, Henderson BE, Le Marchand L, Kolonel LN, Goodman MT. Prediagnostic leptin, adiponectin, C-reactive protein, and the risk of postmenopausal breast cancer. Cancer Prev Res (Phila). 2013; 6:188-95.

81. Chen DC, Chung YF, Yeh YT, Chaung HC, Kuo FC, Fu OY, Chen HY, Hou MF, Yuan SSF. Serum adiponectin and leptin levels in Taiwanese breast cancer patients. Cancer Lett. 2006; 237:109-14. 
82. Stocks T, Lukanova A, Johansson M, Rinaldi S, Palmqvist R, Hallmans G, Kaaks R, Stattin P. Components of the metabolic syndrome and colorectal cancer risk; a prospective study. Int J Obes (Lond). 2008; 32:304-14.

83. Ashizawa N, Yahata T, Quan J, Adachi S, Yoshihara K, Tanaka K. Serum leptin-adiponectin ratio and endometrial cancer risk in postmenopausal female subjects. Gynecol Oncol. 2010; 119:65-9.

84. Pollak M. Insulin and insulin-like growth factor signalling in neoplasia. Nat Rev Cancer. 2008; 8:915-28.

85. Kurmasheva RT, Houghton PJ. IGF-I mediated survival pathways in normal and malignant cells. Biochim Biophys Acta. 2006; 1766:1-22.

86. Hefetz-Sela S, Scherer PE. Adipocytes: impact on tumor growth and potential sites for therapeutic intervention. Pharmacol Ther. 2013; 138:197-210.

87. D'Esposito V, Passaretti F, Hammarstedt A, Liguoro D, Terracciano D, Molea G, Canta L, Miele C, Smith U, Beguinot F, Formisano P. Adipocyte-released insulin-like growth factor-1 is regulated by glucose and fatty acids and controls breast cancer cell growth in vitro. Diabetologia. 2012; 55:2811-22.

88. Bell LN, Ward JL, Degawa-Yamauchi M, Bovenkerk JE, Jones R, Cacucci BM, Gupta CE, Sheridan C, Sheridan K, Shankar SS, Steinberg HO, March KL, Considine RV. Adipose tissue production of hepatocyte growth factor contributes to elevated serum HGF in obesity. Am J Physiol Endocrinol Metab. 2006; 291: E843-848.

89. Beviglia L, Matsumoto K, Lin CS, Ziober BL, Kramer RH. Expression of the c-Met/HGF receptor in human breast carcinoma: correlation with tumor progression. Int J Cancer. 1997; 74:301-9.

90. Wong AS, Pelech SL, Woo MM, Yim G, Rosen B, Ehlen T, Leung PC, Auersperg N. Coexpression of hepatocyte growth factor-Met: an early step in ovarian carcinogenesis? Oncogene. 2001; 20:1318-28.

91. Edakuni G, Sasatomi E, Satoh T, Tokunaga O, Miyazaki K. Expression of the hepatocyte growth factor/c-Met pathway is increased at the cancer front in breast carcinoma. Pathol Int. 2001; 51:172-8.

92. Rahimi N, Saulnier R, Nakamura T, Park M, Elliott B. Role of hepatocyte growth factor in breast cancer: a novel mitogenic factor secreted by adipocytes. DNA Cell Biol. 1994; 13:1189-97.

93. Takayama H, LaRochelle WJ, Sharp R, Otsuka T, Kriebel P, Anver M, Aaronson SA, Merlino G. Diverse tumorigenesis associated with aberrant development in mice overexpressing hepatocyte growth factor/scatter factor. Proc Natl Acad Sci USA. 1997; 94:701-6.

94. Sundaram S, Le TL, Essaid L, Freemerman AJ, Huang MJ, Galanko JA, McNaughton KK, Bendt KM, Darr DB, Troester MA, Makowski L. Weight Loss Reversed ObesityInduced HGF/c-Met Pathway and Basal-Like Breast Cancer Progression. Front Oncol. 2014; 4: 175.
95. Sieh W, Köbel M, Longacre TA, Bowtell DD, deFazio A, Goodman MT, Høgdall E, Deen S, Wentzensen N, Moysich KB, Brenton JD, Clarke BA, Menon U, et al. Hormone-receptor expression and ovarian cancer survival: an Ovarian Tumor Tissue Analysis consortium study. Lancet Oncol. 2013; 14: 853-62.

96. Heldring N, Pike A, Andersson S, Matthews J, Cheng G, Hartman J, Tujague M, Ström A, Treuter E, Warner M, Gustafsson JA. Estrogen receptors: how do they signal and what are their targets. Physiol Rev. 2007; 87: 905-31.

97. Cleland WH, Mendelson CR, Simpson ER. Aromatase activity of membrane fractions of human adipose tissue stromal cells and adipocytes. Endocrinology. 1983; 113:2155-60.

98. Price T, Aitken J, Head J, Mahendroo M, Means G, Simpson E. Determination of aromatase cytochrome P450 messenger ribonucleic acid in human breast tissue by competitive polymerase chain reaction amplification. J Clin Endocrinol Metab. 1992; 74:1247-52.

99. Zhao Y, Agarwal VR, Mendelson CR, Simpson ER. Estrogen biosynthesis proximal to a breast tumor is stimulated by PGE2 via cyclic AMP, leading to activation of promoter II of the CYP19 (aromatase) gene. Endocrinology. $1996 ; 137: 5739-42$.

100. Agarwal VR, Bulun SE, Leitch M, Rohrich R, Simpson ER. Use of alternative promoters to express the aromatase cytochrome P450 (CYP19) gene in breast adipose tissues of cancer-free and breast cancer patients. J Clin Endocrinol Metab. 1996; 81:3843-9.

101. Arendt LM, McCready J, Keller PJ, Baker DD, Naber SP, Seewaldt V, Kuperwasser C. Obesity promotes breast cancer by CCL2-mediated macrophage recruitment and angiogenesis. Cancer Res. 2013; 73:6080-93.

102. Howe LR, Subbaramaiah K, Hudis CA, Dannenberg AJ. Molecular pathways: adipose inflammation as a mediator of obesity-associated cancer. Clin Cancer Res. 2013; 19:607483.

103. Fisher DT, Appenheimer MM, Evans SS. The two faces of IL-6 in the tumor microenvironment. Semin Immunol. $2014 ; 26: 38-47$.

104. Kim HJ, Lee YS, Won EH, Chang IH, Kim TH, Park ES, Kim MK, Kim W, Myung SC. Expression of resistin in the prostate and its stimulatory effect on prostate cancer cell proliferation. BJU Int. 2011; 108: E77-83.

105. Deshmukh SK, Srivastava SK, Bhardwaj A, Singh AP, Tyagi N, Marimuthu S, Dyess DL, Dal Zotto V, Carter JE, Singh S. Resistin and interleukin-6 exhibit racially-disparate expression in breast cancer patients, display molecular association and promote growth and aggressiveness of tumor cells through STAT3 activation. Oncotarget. 2015; 6:11231-41. doi: 10.18632/oncotarget.3591.

106. Lee S, Lee HC, Kwon YW, Lee SE, Cho Y, Kim J, Lee S, Kim JY, Lee J, Yang HM, Mook-Jung I, Nam KY, Chung J, et al. Adenylyl Cyclase-Associated Protein 1(CAP1) is a Receptor for Human Resistin and Mediates Inflammatory Actions of Human Monocytes. Cell Metab. 2014; 19:484-97. 
107. Steppan CM, Bailey ST, Bhat S, Brown EJ, Banerjee RR, Wright CM, Patel HR, Ahima RS, Lazar MA. The hormone resistin links obesity to diabetes. Nature. 2001; 409:307-12.

108. Feng Z, Zhang H. Resistin and Cancer Risk: A MiniReview. Endocrinol Metab Syndr. 2011 [cited 2017 Jan 25]. Available from: https://www.omicsonline.org/ resistin-and-cancer-risk-a-mini-review-2161-1017.S4-003. php?aid=3760.

109. Hanahan D, Weinberg RA. The hallmarks of cancer. Cell. 2000; 100:57-70.

110. Cao Y. Adipose tissue angiogenesis as a therapeutic target for obesity and metabolic diseases. Nat Rev Drug Discov. 2010; 9:107-15.

111. Cao Y. Angiogenesis and vascular functions in modulation of obesity, adipose metabolism, and insulin sensitivity. Cell Metab. 2013; 18:478-89.

112. Mick GJ, Wang X, McCormick K. White adipocyte vascular endothelial growth factor: regulation by insulin. Endocrinology. 2002; 143:948-53.

113. Gonzalez-Perez RR, Lanier V, Newman G. Leptin's ProAngiogenic Signature in Breast Cancer. Cancers. 2013; 5:1140-62.

114. Gonzalez-Perez RR, Xu Y, Guo S, Watters A, Zhou W, Leibovich SJ. Leptin upregulates VEGF in breast cancer via canonic and non-canonical signalling pathways and NFkappaB/HIF-1alpha activation. Cell Signal. 2010; 22:1350-62.

115. Denzel MS, Hebbard LW, Shostak G, Shapiro L, Cardiff RD, Ranscht B. Adiponectin deficiency limits tumor vascularization in the MMTV-PyV-mT mouse model of mammary cancer. Clin Cancer Res. 2009; 15:3256-64.

116. Landskroner-Eiger S, Qian B, Muise ES, Nawrocki AR, Berger JP, Fine EJ, Koba W, Deng Y, Pollard JW, Scherer PE. Proangiogenic contribution of adiponectin toward mammary tumor growth in vivo. Clin Cancer Res. 2009; 15:3265-76.

117. Mu H, Ohashi R, Yan S, Chai H, Yang H, Lin P, Yao Q, Chen $\mathrm{C}$. Adipokine resistin promotes in vitro angiogenesis of human endothelial cells. Cardiovasc Res. 2006; 70:146-57.

118. Saiki A, Watanabe F, Murano T, Miyashita Y, Shirai K. Hepatocyte growth factor secreted by cultured adipocytes promotes tube formation of vascular endothelial cells in vitro. Int J Obes 2005. 2006; 30:1676-84.

119. Ouchi N, Kobayashi H, Kihara S, Kumada M, Sato K, Inoue T, Funahashi T, Walsh K. Adiponectin stimulates angiogenesis by promoting cross-talk between AMPactivated protein kinase and Akt signaling in endothelial cells. J Biol Chem. 2004; 279:1304-9.

120. Shibata R, Ouchi N, Kihara S, Sato K, Funahashi T, Walsh K. Adiponectin stimulates angiogenesis in response to tissue ischemia through stimulation of amp-activated protein kinase signaling. J Biol Chem. 2004; 279:28670-4.

121. Bråkenhielm E, Veitonmäki N, Cao R, Kihara S, Matsuzawa Y, Zhivotovsky B, Funahashi T, Cao Y.
Adiponectin-induced antiangiogenesis and antitumor activity involve caspase-mediated endothelial cell apoptosis. Proc Natl Acad Sci USA. 2004; 101: 2476-81.

122. Man K, Ng KTP, Xu A, Cheng Q, Lo CM, Xiao JW, Sun BS, Lim ZXH, Cheung JS, Wu EX, Sun CKW, Poon RTP, Fan ST. Suppression of liver tumor growth and metastasis by adiponectin in nude mice through inhibition of tumor angiogenesis and downregulation of Rho kinase/IFN-inducible protein 10/matrix metalloproteinase 9 signaling. Clin Cancer Res. 2010; 16:967-77.

123. Dobson DE, Kambe A, Block E, Dion T, Lu H, Castellot JJ, Spiegelman BM. 1-Butyryl-glycerol: a novel angiogenesis factor secreted by differentiating adipocytes. Cell. 1990; 61:223-30.

124. Lim S, Hosaka K, Nakamura M, Cao Y. Co-option of pre-existing vascular beds in adipose tissue controls tumor growth rates and angiogenesis. Oncotarget. 2016; 7:38282-91. doi: 10.18632/oncotarget.9436.

125. Warburg O. On the origin of cancer cells. Science. 1956; 123:309-14.

126. Sonveaux P, Végran F, Schroeder T, Wergin MC, Verrax J, Rabbani ZN, De Saedeleer CJ, Kennedy KM, Diepart C, Jordan BF, Kelley MJ, Gallez B, Wahl ML, et al. Targeting lactate-fueled respiration selectively kills hypoxic tumor cells in mice. J Clin Invest. 2008; 118: 3930-42.

127. Yang C, Sudderth J, Dang T, Bachoo RM, Bachoo RG, McDonald JG, DeBerardinis RJ. Glioblastoma cells require glutamate dehydrogenase to survive impairments of glucose metabolism or Akt signaling. Cancer Res. 2009; 69:7986-93.

128. Pavlides S, Whitaker-Menezes D, Castello-Cros R, Flomenberg N, Witkiewicz AK, Frank PG, Casimiro MC, Wang C, Fortina P, Addya S, Pestell RG, MartinezOutschoorn UE, Sotgia F, et al. The reverse Warburg effect: aerobic glycolysis in cancer associated fibroblasts and the tumor stroma. Cell Cycle. 2009; 8:3984-4001.

129. Whitaker-Menezes D, Martinez-Outschoorn UE, Lin Z, Ertel A, Flomenberg N, Witkiewicz AK, Birbe RC, Howell A, Pavlides S, Gandara R, Pestell RG, Sotgia F, Philp NJ, et al. Evidence for a stromal-epithelial "lactate shuttle" in human tumors: MCT4 is a marker of oxidative stress in cancer-associated fibroblasts. Cell Cycle. 2011; 10:1772-83.

130. Soares AF, Guichardant M, Cozzone D, BernoudHubac N, Bouzaïdi-Tiali N, Lagarde M, Géloën A. Effects of oxidative stress on adiponectin secretion and lactate production in 3T3-L1 adipocytes. Free Radic Biol Med. $2005 ; 38: 882-9$.

131. Pérez de Heredia F, Wood IS, Trayhurn P. Hypoxia stimulates lactate release and modulates monocarboxylate transporter (MCT1, MCT2, and MCT4) expression in human adipocytes. Pflugers Arch. 2010; 459:509-18.

132. Park J, Morley TS, Kim M, Clegg DJ, Scherer PE. Obesity and cancer--mechanisms underlying tumour progression and recurrence. Nat Rev Endocrinol. 2014; 10:455-65. 
133. Diedrich JD, Rajagurubandara E, Herroon MK, Mahapatra G, Hüttemann M, Podgorski I. Bone marrow adipocytes promote the warburg phenotype in metastatic prostate tumors via HIF-1 $\alpha$ activation. Oncotarget. 2016; 7:64854-77. doi: 10.18632/oncotarget.11712.

134. Balaban S, Shearer RF, Lee LS, van Geldermalsen M, Schreuder M, Shtein HC, Cairns R, Thomas KC, Fazakerley DJ, Grewal T, Holst J, Saunders DN, Hoy AJ. Adipocyte lipolysis links obesity to breast cancer growth: adipocyte-derived fatty acids drive breast cancer cell proliferation and migration. Cancer Metab. 2017; 5:1.

135. Wang YY, Attané C, Milhas D, Dirat B, Dauvillier S, Guerard A, Gilhodes J, Lazar I, Alet N, Laurent V, Le Gonidec S, Biard D, Hervé C, et al. Mammary adipocytes stimulate breast cancer invasion through metabolic remodeling of tumor cells. JCI Insight. 2017; 2:e87489.

136. Currie E, Schulze A, Zechner R, Walther TC, Farese RV. Cellular fatty acid metabolism and cancer. Cell Metab. 2013; 18:153-61.

137. Sagar G, Sah RP, Javeed N, Dutta SK, Smyrk TC, Lau JS, Giorgadze N, Tchkonia T, Kirkland JL, Chari ST, Mukhopadhyay D. Pathogenesis of pancreatic cancer exosome-induced lipolysis in adipose tissue. Gut. 2016; 65:1165-74.

138. Das SK, Eder S, Schauer S, Diwoky C, Temmel H, Guertl B, Gorkiewicz G, Tamilarasan KP, Kumari P, Trauner M, Zimmermann R, Vesely P, Haemmerle G, et al. Adipose triglyceride lipase contributes to cancer-associated cachexia. Science. 2011; 333:233-8.

139. Tisdale MJ. Cachexia in cancer patients. Nat Rev Cancer. 2002; 2:862-71.

140. Kir S, White JP, Kleiner S, Kazak L, Cohen P, Baracos VE, Spiegelman BM. Tumour-derived PTH-related protein triggers adipose tissue browning and cancer cachexia. Nature. 2014; 513:100-4.

141. Kir S, Komaba H, Garcia AP, Economopoulos KP, Liu W, Lanske B, Hodin RA, Spiegelman BM. PTH/PTHrP Receptor Mediates Cachexia in Models of Kidney Failure and Cancer. Cell Metab. 2015.

142. Li K, Wei L, Huang Y, Wu Y, Su M, Pang X, Wang N, Ji F, Zhong C, Chen T. Leptin promotes breast cancer cell migration and invasion via IL-18 expression and secretion. Int J Oncol. 2016; 48:2479-87.

143. Brown MD, Hart C, Gazi E, Gardner P, Lockyer N, Clarke N. Influence of omega-6 PUFA arachidonic acid and bone marrow adipocytes on metastatic spread from prostate cancer. Br J Cancer. 2010; 102:403-13.

144. Lazar I, Clement E, Dauvillier S, Milhas D, Ducoux-Petit M, Le Gonidec S, Moro C, Soldan V, Dalle S, Balor S, Golzio M, Burlet-Schiltz O, Valet P, et al. Adipocyte exosomes promote melanoma aggressiveness through fatty acid oxidation: a novel mechanism linking obesity and cancer. Cancer Res. 2016.

145. Kubo Y, Kaidzu S, Nakajima I, Takenouchi K, Nakamura F. Organization of extracellular matrix components during differentiation of adipocytes in long-term culture. In Vitro Cell Dev Biol Anim. 2000; 36:38-44.

146. Iyengar P, Combs TP, Shah SJ, Gouon-Evans V, Pollard JW, Albanese C, Flanagan L, Tenniswood MP, Guha C, Lisanti MP, Pestell RG, Scherer PE. Adipocyte-secreted factors synergistically promote mammary tumorigenesis through induction of anti-apoptotic transcriptional programs and proto-oncogene stabilization. Oncogene. 2003; 22:6408-23.

147. Iyengar P, Espina V, Williams TW, Lin Y, Berry D, Jelicks LA, Lee H, Temple K, Graves R, Pollard J, Chopra N, Russell RG, Sasisekharan R, et al. Adipocytederived collagen VI affects early mammary tumor progression in vivo, demonstrating a critical interaction in the tumor/stroma microenvironment. J Clin Invest. 2005; 115:1163-76.

148. Park J, Scherer PE. Adipocyte-derived endotrophin promotes malignant tumor progression. J Clin Invest. 2012; 122:4243-56.

149. Chavey C, Mari B, Monthouel MN, Bonnafous S, Anglard P, Van Obberghen E, Tartare-Deckert S. Matrix metalloproteinases are differentially expressed in adipose tissue during obesity and modulate adipocyte differentiation. J Biol Chem. 2003; 278:11888-96.

150. Kessenbrock K, Plaks V, Werb Z. Matrix metalloproteinases: regulators of the tumor microenvironment. Cell. 2010; 141:52-67.

151. Matziari M, Dive V, Yiotakis A. Matrix metalloproteinase 11 (MMP-11; stromelysin-3) and synthetic inhibitors. Med Res Rev. 2007; 27:528-52.

152. Motrescu ER, Blaise S, Etique N, Messaddeq N, Chenard MP, Stoll I, Tomasetto C, Rio MC. Matrix metalloproteinase-11/stromelysin-3 exhibits collagenolytic function against collagen VI under normal and malignant conditions. Oncogene. 2008; 27:6347-55.

153. Noël A, Boulay A, Kebers F, Kannan R, Hajitou A, CalbergBacq CM, Basset P, Rio MC, Foidart JM. Demonstration in vivo that stromelysin-3 functions through its proteolytic activity. Oncogene. 2000; 19: 1605-12.

154. Andarawewa KL, Boulay A, Masson R, Mathelin C, Stoll I, Tomasetto C, Chenard MP, Gintz M, Bellocq JP, Rio MC. Dual stromelysin-3 function during natural mouse mammary tumor virus-ras tumor progression. Cancer Res. 2003; 63:5844-9.

155. Jia L, Wang S, Cao J, Zhou H, Wei W, Zhang J. siRNA targeted against matrix metalloproteinase 11 inhibits the metastatic capability of murine hepatocarcinoma cell Hca-F to lymph nodes. Int J Biochem Cell Biol. 2007; 39:2049-62.

156. Cheng CW, Yu JC, Wang HW, Huang CS, Shieh JC, Fu YP, Chang CW, Wu PE, Shen CY. The clinical implications of MMP-11 and CK-20 expression in human breast cancer. Clin Chim Acta. 2010; 411:234-41.

157. Jones LE, Humphreys MJ, Campbell F, Neoptolemos JP, Boyd MT. Comprehensive analysis of matrix 
metalloproteinase and tissue inhibitor expression in pancreatic cancer: increased expression of matrix metalloproteinase-7 predicts poor survival. Clin Cancer Res. 2004; 10:2832-45.

158. Thewes M, Pohlmann G, Atkinson M, Mueller J, Pütz B, Höfler H. Stromelysin-3 (ST-3) mRNA expression in colorectal carcinomas. Localization and clinicopathologic correlations. Diagn Mol Pathol. 1996; 5: 284-90.

159. Yeh WL, Lu DY, Lee MJ, Fu WM. Leptin induces migration and invasion of glioma cells through MMP-13 production. Glia. 2009; 57:454-64.

160. Rosenthal EL, Johnson TM, Allen ED, Apel IJ, Punturieri A, Weiss SJ. Role of the plasminogen activator and matrix metalloproteinase systems in epidermal growth factorand scatter factor-stimulated invasion of carcinoma cells. Cancer Res. 1998; 58:5221-30.

161. Monvoisin A, Bisson C, Si-Tayeb K, Balabaud C, Desmoulière $\mathrm{A}$, Rosenbaum J. Involvement of matrix metalloproteinase type-3 in hepatocyte growth factorinduced invasion of human hepatocellular carcinoma cells. Int J Cancer. 2002; 97:157-62.

162. Pramanik R, Sheng X, Ichihara B, Heisterkamp N, Mittelman SD. Adipose tissue attracts and protects acute lymphoblastic leukemia cells from chemotherapy. Leuk Res. 2013; 37:503-9.

163. Laurent V, Guérard A, Mazerolles C, Le Gonidec S, Toulet A, Nieto L, Zaidi F, Majed B, Garandeau D, Socrier Y, Golzio M, Cadoudal T, Chaoui K, et al. Periprostatic adipocytes act as a driving force for prostate cancer progression in obesity. Nat Commun. 2016; 7:10230.

164. Templeton ZS, Lie WR, Wang W, Rosenberg-Hasson Y, Alluri RV, Tamaresis JS, Bachmann MH, Lee K, Maloney WJ, Contag CH, King BL. Breast Cancer Cell Colonization of the Human Bone Marrow Adipose Tissue Niche. Neoplasia. 2015; 17:849-61.

165. Parekh N, Chandran U, Bandera EV. Obesity in cancer survival. Annu Rev Nutr. 2012; 32:311-42.

166. Paraiso KHT, Smalley KSM. Fibroblast-mediated drug resistance in cancer. Biochem Pharmacol. 2013; 85:1033-41.

167. Park J, Euhus DM, Scherer PE. Paracrine and endocrine effects of adipose tissue on cancer development and progression. Endocr Rev. 2011; 32:550-70.

168. Lyman GH. Weight-based chemotherapy dosing in obese patients with cancer: back to the future. J Oncol Pract. 2012; 8:e62-64.

169. Behan JW, Avramis VI, Yun JP, Louie SG, Mittelman SD. Diet-induced obesity alters vincristine pharmacokinetics in blood and tissues of mice. Pharmacol Res. 2010; 61:385-90.

170. Jain R, Chung SM, Jain L, Khurana M, Lau SWJ, Lee JE, Vaidyanathan J, Zadezensky I, Choe S, Sahajwalla CG. Implications of obesity for drug therapy: limitations and challenges. Clin Pharmacol Ther. 2011; 90:77-89.

171. King CR, Spiotto MT, Kapp DS. Obesity and risk of biochemical failure for patients receiving salvage radiotherapy after prostatectomy. Int J Radiat Oncol Biol Phys. 2009; 73:1017-22.
172. Strom SS, Kamat AM, Gruschkus SK, Gu Y, Wen S, Cheung MR, Pisters LL, Lee AK, Rosser CJ, Kuban DA. Influence of obesity on biochemical and clinical failure after external-beam radiotherapy for localized prostate cancer. Cancer. 2006; 107:631-9.

173. Wang LS, Murphy CT, Ruth K, Zaorsky NG, Smaldone MC, Sobczak ML, Kutikov A, Viterbo R, Horwitz EM. Impact of obesity on outcomes after definitive dose-escalated intensity-modulated radiotherapy for localized prostate cancer. Cancer. 2015; 121:3010-7.

174. Zilli T, Nguyen TV, Bahary JP, Chagnon M, Dufresne A, Taussky D. Prognostic impact of abdominal adiposity, waist circumference and body mass index in patients with intermediate-risk prostate cancer treated with radiotherapy. Int J Obes (Lond). 2011; 35:1421-6.

175. Geinitz H, Thamm R, Mueller T, Jess K, Zimmermann FB, Molls M, Nieder C. Impact of body mass index on outcomes after conformal radiotherapy in patients with prostate cancer. Int J Radiat Oncol Biol Phys. 2011; 81:16-22.

176. Shridhar R, Hayman T, Hoffe SE, Weber J, Almhanna K, Chuong M, Karl RC, Meredith KL. Body mass index and survival in esophageal adenocarcinoma treated with chemoradiotherapy followed by esophagectomy. J Gastrointest Surg. 2012; 16:1296-302.

177. Ewertz M, Jensen MB, Gunnarsdóttir KÁ, Højris I, Jakobsen EH, Nielsen D, Stenbygaard LE, Tange UB, Cold S. Effect of obesity on prognosis after early-stage breast cancer. J Clin Oncol. 2011; 29:25-31.

178. Jiralerspong S, Kim ES, Dong W, Feng L, Hortobagyi GN, Giordano SH. Obesity, diabetes, and survival outcomes in a large cohort of early-stage breast cancer patients. Ann Oncol. 2013; 24:2506-14.

179. Simkens LHJ, Koopman M, Mol L, Veldhuis GJ, Ten Bokkel Huinink D, Muller EW, Derleyn VA, Teerenstra S, Punt CJA. Influence of body mass index on outcome in advanced colorectal cancer patients receiving chemotherapy with or without targeted therapy. Eur J Cancer. 2011; 47:2560-7.

180. Guiu B, Petit JM, Bonnetain F, Ladoire S, Guiu S, Cercueil JP, Krausé D, Hillon P, Borg C, Chauffert B, Ghiringhelli F. Visceral fat area is an independent predictive biomarker of outcome after first-line bevacizumab-based treatment in metastatic colorectal cancer. Gut. 2010; 59:341-7.

181. Patel GS, Ullah S, Beeke C, Hakendorf P, Padbury R, Price TJ, Karapetis CS. Association of BMI with overall survival in patients with $\mathrm{mCRC}$ who received chemotherapy versus EGFR and VEGF-targeted therapies. Cancer Med. 2015; 4:1461-71.

182. Crozier JA, Moreno-Aspitia A, Ballman KV, Dueck AC, Pockaj BA, Perez EA. Effect of body mass index on tumor characteristics and disease-free survival in patients from the HER2-positive adjuvant trastuzumab trial N9831. Cancer. 2013; 119:2447-54.

183. Sethi T, Rintoul RC, Moore SM, MacKinnon AC, Salter D, Choo C, Chilvers ER, Dransfield I, Donnelly SC, Strieter R, 
Haslett C. Extracellular matrix proteins protect small cell lung cancer cells against apoptosis: a mechanism for small cell lung cancer growth and drug resistance in vivo. Nat Med. 1999; 5:662-8.

184. Hazlehurst LA, Dalton WS. Mechanisms associated with cell adhesion mediated drug resistance (CAM-DR) in hematopoietic malignancies. Cancer Metastasis Rev. 2001; 20:43-50.

185. Sherman-Baust CA, Weeraratna AT, Rangel LBA, Pizer ES, Cho KR, Schwartz DR, Shock T, Morin PJ. Remodeling of the extracellular matrix through overexpression of collagen VI contributes to cisplatin resistance in ovarian cancer cells. Cancer Cell. 2003; 3:377-86.

186. Satoh M, Cherian MG, Imura N, Shimizu H. Modulation of resistance to anticancer drugs by inhibition of metallothionein synthesis. Cancer Res. 1994; 54:5255-7.

187. Faller WJ, Rafferty M, Hegarty S, Gremel G, Ryan D, Fraga MF, Esteller M, Dervan PA, Gallagher WM. Metallothionein 1E is methylated in malignant melanoma and increases sensitivity to cisplatin-induced apoptosis. Melanoma Res. 2010; 20:392-400.

188. Park J, Morley TS, Scherer PE. Inhibition of endotrophin, a cleavage product of collagen VI, confers cisplatin sensitivity to tumours. EMBO Mol Med. 2013; 5:935-48.

189. Sun K, Park J, Gupta OT, Holland WL, Auerbach P, Zhang N, Goncalves Marangoni R, Nicoloro SM, Czech MP, Varga J, Ploug T, An Z, Scherer PE. Endotrophin triggers adipose tissue fibrosis and metabolic dysfunction. Nat Commun. 2014; 5: 3485.

190. Behan JW, Yun JP, Proektor MP, Ehsanipour EA, Arutyunyan A, Moses AS, Avramis VI, Louie SG, Butturini A, Heisterkamp N, Mittelman SD. Adipocytes impair leukemia treatment in mice. Cancer Res. 2009; 69:7867-74.

191. Chi M, Chen J, Ye Y, Tseng HY, Lai F, Tay KH, Jin L, Guo ST, Jiang CC, Zhang XD. Adipocytes contribute to resistance of human melanoma cells to chemotherapy and targeted therapy. Curr Med Chem. 2014; 21:1255-67.

192. Bartucci M, Svensson S, Ricci-Vitiani L, Dattilo R, Biffoni M, Signore M, Ferla R, De Maria R, Surmacz E.
Obesity hormone leptin induces growth and interferes with the cytotoxic effects of 5-fluorouracil in colorectal tumor stem cells. Endocr Relat Cancer. 2010; 17:823-33.

193. Bochet L, Meulle A, Imbert S, Salles B, Valet P, Muller C. Cancer-associated adipocytes promotes breast tumor radioresistance. Biochem Biophys Res Commun. 2011; 411:102-6.

194. Duong MN, Cleret A, Matera EL, Chettab K, Mathé D, Valsesia-Wittmann S, Clémenceau B, Dumontet C. Adipose cells promote resistance of breast cancer cells to trastuzumab-mediated antibody-dependent cellular cytotoxicity. Breast Cancer Res. 2015; 17:57.

195. Au Yeung CL, Co NN, Tsuruga T, Yeung TL, Kwan SY, Leung CS, Li Y, Lu ES, Kwan K, Wong KK, Schmandt R, $\mathrm{Lu} \mathrm{KH}$, Mok SC. Exosomal transfer of stroma-derived miR21 confers paclitaxel resistance in ovarian cancer cells through targeting APAF1. Nat Commun. 2016; 7: 11150.

196. Sheng X, Tucci J, Parmentier JH, Ji L, Behan JW, Heisterkamp N, Mittelman SD. Adipocytes cause leukemia cell resistance to daunorubicin via oxidative stress response. Oncotarget. 2016; 7:73147-73159. doi: 10.18632/ oncotarget. 12246.

197. Liu Z, Xu J, He J, Liu H, Lin P, Wan X, Navone NM, Tong Q, Kwak LW, Orlowski RZ, Yang J. Mature adipocytes in bone marrow protect myeloma cells against chemotherapy through autophagy activation. Oncotarget. 2015; 6:34329-41. doi: 10.18632/oncotarget.6020.

198. Ehsanipour EA, Sheng X, Behan JW, Wang X, Butturini A, Avramis VI, Mittelman SD. Adipocytes cause leukemia cell resistance to L-asparaginase via release of glutamine. Cancer Res. 2013; 73:2998-3006.

199. De Angel RE, Blando JM, Hogan MG, Sandoval MA, Lansakara-P DSP, Dunlap SM, Hursting SD, Cui Z. Stearoyl gemcitabine nanoparticles overcome obesityinduced cancer cell resistance to gemcitabine in a mouse postmenopausal breast cancer model. Cancer Biol Ther. 2013; 14:357-64. 